\title{
A reinvestigation of Diichnia Read from the New Albany Shale of Kentucky
}

\author{
Charles B. Beck, ${ }^{a}$ Jean Galtier, ${ }^{\mathrm{b}}$ and William E. Stein, Jr. ${ }^{\mathrm{c}}$ \\ ${ }^{2}$ Museum of Paleontology and Department of Biology, University of Michigan, Ann Arbor, MI 48109, USA

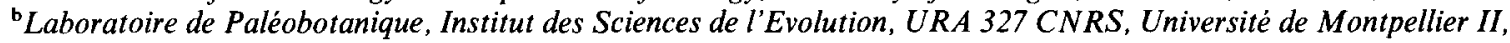 \\ 34095 Montpellier, France \\ ${ }^{\circ}$ Center for Evolution and Paleoenvironment, State University of New York, Binghamton, NY 13902-6000, USA
}

(Received January 27, 1992; revised and accepted July 2, 1992)

\begin{abstract}
Beck, C.B., Galtier, J. and Stein, W.E, 1992. A reinvestigation of Diichnia Read from the New Albany Shale of Kentucky. Rev. Palaeobot. Palynol., 75: 1-32.

The type material of Diichnia Read, supplemented by several additional specimens, has been restudied and a lectotype designated. Special attention has been paid to the nature of the primary vascular system, the pattern of leaf-trace divergence, branching of the leaf traces to form the petiolar vascular supply, and the zone of parenchyma just outside the secondary phloem. Generic and species diagnoses are emended and a new species, $D$. readii, is established.
\end{abstract}

\section{Introduction}

This paper is part of a major reinvestigation of genera of the Calamopityaceae being undertaken by the team of Jean Galtier, Brigitte MeyerBerthaud, William Stein and Charles Beck supported by NSF and CNRS. Other papers generated by this project to date present our studies of Bostonia (Stein and Beck, 1992) and a new genus, Triichnia (Galtier and Beck, 1992). We present herein the results of our study of the type material of Diichnia kentuckiensis Read supplemented by investigation of two specimens not included in the original descriptions of this genus.

Diichnia was established by Read $(1936 a, b)$ on the basis of three specimens collected from "the top of the New Albany Shale" one half mile west of Junction City, Kentucky. More recent workers (Campbell, 1946; Haas, 1956) have recognized the nodule layer from which these fossils were derived as the Falling Run Member of the Sanderson

Correspondence to: Dr. C.B. Beck, University of Michigan, Museum of Paleontology, Ann Arbor, MI 48109, USA. Fax: 3137634690 .
Formation. They, as well as Sandberg et al. (1978) and Ettensohn et al. (1988) consider this stratum to be of basal lower Mississippian (Tournaisian) age.

Read (1936b) characterized Diichnia as having a 5-angled pith consisting of parenchyma intermixed with tracheids, a condition that he termed a "mixed pith". He described and illustrated five mesarch primary vascular bundles, one associated with each angle of the pith. By far the most distinctive feature of Diichnia is the production of a pair of leaf traces that diverge radially from two widely separated vascular bundles in adjacent angles of the pith, and that together initiate the vascular supply of a single leaf. Another feature emphasized by Read is the presence in the cortex of structures he described as "canals" or "cavities ... which appear to be of secretory function and lysigenous origin". Read also ascribed these structures to the pith (Read, 1936b, p. 154), but they do not occur there (see later section for a detailed analysis of these structures). Other features noted by Read are the manoxylic secondary wood, the tangential "elongation" (widening and subsequent 
division) of bundles that will provide the petiolar vascular supply, and the $2 / 5$ phyllotaxy.

Although differing in the origin of the vascular supply to leaves, Diichnia was considered by Read (1936a, b) to be closely related to Calamopitys, and in a subsequent paper (Read, 1937) recognized it as the most advanced taxon in the family. He suggested initially (Read, 1936b) that the petiole, Kalymma (Calamopteris) hypocrepis, belonged to Diichnia, but he subsequently modified that view, concluding that petioles known as Kalymma resinosa (Read, 1937, p. 88) "are undoubtedly derived from . . Diichnia". This conclusion was based on the occurrence in the cortex of both $K$. resinosa and Diichnia of similar "lysigenous secretory sacs or ducts".

\section{Materials and methods}

Five specimens have been studied bearing the following US National Museum catalog numbers:
$41245,41246,41247,356463$, and 172325. The first three were the basis of Read's studies, but he had available only two transverse sections of specimen 41247, numbered 487 and 488 . The fourth, an uncut specimen, was discovered by Charles Beck in a loan from the USNM collections. The fifth specimen, from which two sections had been prepared, and which has been assigned the USNM catalog number 172325 , is apparently also a Diichnia. The two original sections were numbered 1055 and 1056. Four of these specimens, which form the basis for this paper, are illustrated in transverse views in Fig. 1.

Specimen 41245 , consisting of 7 longitudinal sections, also bears the number Da 2-17, and the notation, "prepared by K.J. Murata for C.B. Read." Specimen 41246 , consisting of 13 transverse sections, also bears the number Da 2-15, and the same notation as the preceding. This specimen (41246) is the source of the illustration in Read's

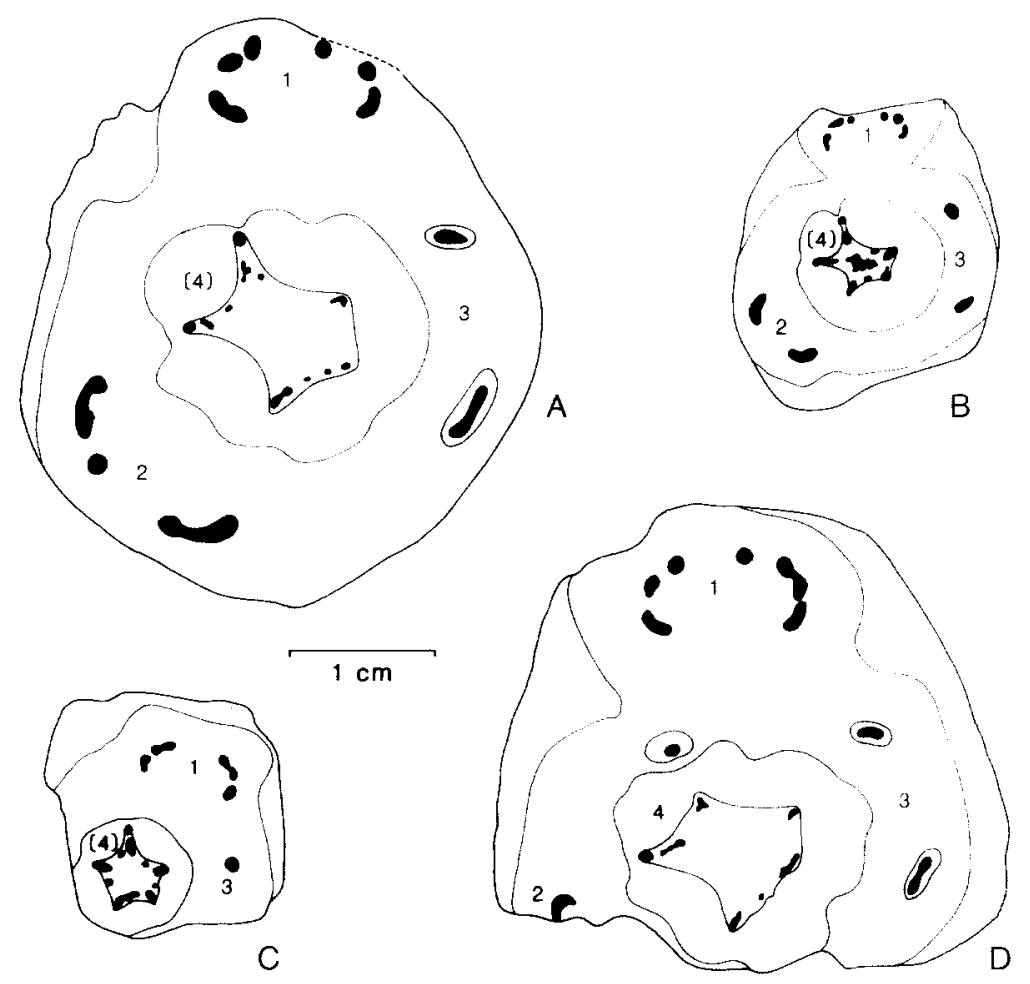

Fig. 1. Camera lucida drawings of transverse sections of Diichnia kentuckiensis (A, B, D) and D. readii (C). Sections A and D may represent the same stem. Vascular supplies and incipient vascular supplies (indicated by numbers in parentheses) to successive leaves are numbered $(I-4)$ in the order in which they originated along the ontogenetic spiral. Note that the two traces from which a leaf vascular supply originates diverge from two separate, adjacent sympodia, and that the divergence of these leaf traces is asynchronous. A. USNM 41246, sec. 478. B. USNM 41247, sec. CB2. C. USNM 172325, sec. 3. D. USNM 356463. sec. 4. 
original, brief description of the genus (Read, 1936a, plate 27, fig. 2). Specimens 41245 and 41246 were the main sources of illustrations in Read's more comprehensive description of the species (1936b). These specimens do not appear to be parts of the same axis. Specimen 41245 is smaller than 41246 , but comparable in diameter to specimen 41247. Like the latter it also contains a central, longitudinal column of tracheary tissue in the pith. Specimens 41245 and 41247 may be parts of a single axis. In the absence of any transverse sections of 41245 , however, we have no way to prove this or even to determine, with certainty, its identity as Diichnia. Thus, we have excluded the use of any data from this specimen in our descriptions and diagnoses. All measurements and descriptions of tissues of $D$. kentuckiensis from longitudinal sections are derived from sections that we have made of specimen 41247 .

In neither paper did Read designate a holotype. However, sections of specimens 41245, 41246 and 41247 were indicated (on the section labels) as syntypes.

Specimens 41247 consists of two transverse sections, 487 and 488, and 23 additional transverse and 20 longitudinal thin sections prepared by Charles Beck from the remaining uncut $4 \mathrm{~cm}$ long stem segment.

Specimen 356463 , only about $1 \mathrm{~cm}$ long, was cut into 8 transverse thin sections by CBB. From specimen 172325 he prepared 19 transverse and 28 longitudinal thin sections to supplement the original sections, 1055 and 1056.

Stelar diagrams (Figs. 4A, B; 5) were prepared according to the method of G.K. Kumari as described by Benzing (1967a).

Figure $7 \mathbf{B}$, prepared by $\mathbf{B}$. Miljour, was derived from five camera lucida diagrams scanned in sequence by a Microtek SCANMAKER as encapsulated postscript files and printed consecutively from an ADOBE IllustraTOR graphics program.

\section{Descriptions}

\section{Specimen USNM 41246}

This specimen (Fig. 1A), with specimen 41245 and two transverse sections of specimen 41247
(Fig. 1B; Plate VI, 1), formed the basis for Read's (1936b) study of Diichnia. He recognized that the origin of the petiolar vascular supply from two separate sites and the tangential elongation of petiolar bundles in the cortex were significant and distinctive features of the genus. He did not, however, have a clear understanding of details of nodal anatomy and he made no effort to analyze stelar architecture. For example, he essentially ignored small vascular bundles that may appear between the larger axial bundles located in the angles of the pith. Read's description of the phloem region also needs expansion and clarification. Furthermore, he provided no measurements of cells and tissue regions. No longitudinal sections of 41426 (which we designate as the lectotype) were made, and all descriptions and illustrations of longitudinal views were made from sections of a different axis, USNM 41245 . We shall provide measurements here of specimen 41246 , but defer description and discussion of the more general aspects of its anatomy to the following section on specimen 356463 since it is essentially identical to 41246 and, we believe, a part of the same specimen.

The stem has a diameter of about $40 \mathrm{~mm}$. The pith measures $5 \times 9 \mathrm{~mm}$ across. Secondary xylem is $4.5 \mathrm{~mm}$ thick and the entire xylem cylinder is $18 \mathrm{~mm}$ in diameter. The maximum tangential distance across a petiolar vascular supply in the stem cortex is $12 \mathrm{~mm}$. Pith parenchyma cells range in transverse diameter from $30-182 \mu \mathrm{m}$. Medullary tracheids vary generally from $30-208 \mu \mathrm{m}$ but exceptionally may measure as much as $416 \mu \mathrm{m}$ in diameter. Metaxylem tracheids in the stem stele are $26-208 \mu \mathrm{m}$ in tranverse dimension, and $26-$ $130 \mu \mathrm{m}$ in leaf traces. In transverse dimensions, tracheids of the secondary xylem range from $26-92 \mu \mathrm{m}$ (commonly $45-65 \mu \mathrm{m}$ ) in radial dimension, and 30-80 (commonly 40-60) $\mu \mathrm{m}$ in tangential dimension. Rays in the secondary xylem are up to $130 \mu \mathrm{m}$ and 1-8 (commonly $4-5$ ) cells wide. They measure as much as $400 \mu \mathrm{m}$ wide near the pith, and $200 \mu \mathrm{m}$ near the periphery of the secondary xylem. Ray cells, as measured in transverse section, are $12-36 \mu \mathrm{m}$ in tangential width and 40 $120 \mu \mathrm{m}$ in radial width.

In the two following sections we provide a more detailed analysis of the tissues immediately sur- 
rounding the secondary xylem, clarify the nature of the "sclerotic nests" in the cortex, and the presumed "lysigenous canals" in the pith. In the Discussion we provide an analysis of stelar morphology and describe in detail the petiolar vascular supply.

\section{Specimen USNM 356463}

This short axis fragment, just one cm long, was discovered among uncut specimens in the USNM collections (Plates I-V; Fig. ID). It has all of the characteristics of specimen 41246 described above, and by Read (1936b), and is, we believe, a distal part of the same axis. It has transverse dimensions of $3.0 \times 3.5 \mathrm{~cm}$. The pith is conspicuously 5 -angled (Plate I, 1; Plate II, 1) and measures $8.0 \times 5.5 \mathrm{~mm}$ across. Pith parenchyma cells range in diameter from 30-188 (average 124) $\mu \mathrm{m}$ with exceptionally large cells achieving diameters up to $420 \mu \mathrm{m}$. Scattered pith tracheids (Plate I, 2, 4, 5; Plate II, 1) range from $56-310 \mu \mathrm{m}$ in transverse dimensions but are typically $140-170 \mu \mathrm{m}$ in diameter. Exceptionally, they may achieve diameters up to $526 \mu \mathrm{m}$ (Plate I, 4). One of five major primary vascular bundles (henceforth referred to as axial bundles) occurs in each angle of the pith (Plate II, 1). These bundles which consist of primary xylem are largely separated from the secondary xylem by a narrow zone of parenchyma (Plate II, 1-3) except at levels of trace divergence. Metaxylem tracheids in these bundles measure $26-150 \mu \mathrm{m}$, exceptionally as large as $208 \mu \mathrm{m}$ in diameter, and have a mean diameter of $70 \mu \mathrm{m}$. Metaxylem tracheids in leaf traces have diameters of less than $130 \mu \mathrm{m}$. Each axial bundle contains one or two protoxylem strands (Plate II. 2). At least two of these bundles are tangentially elongate, nearly parallel with the boundary of the pith (Plate II, 1, 3), suggesting that a bundle will diverge laterally from each at a higher level, or that one has fused with each at a lower level. It should also be noted that a small bundle containing protoxylem occupies a position between two axial bundles (Plate II, 1, at arrow; Fig. 1D).

Traces depart radially from adjacent axial bundles (Plate III, 1-3; Fig. 1D). The pair divide additionally in the cortex to produce the petiolar vascular supply (Plate IV, 3, 4; Fig. 6A) which has a maximum tangential width of $11 \mathrm{~mm}$. Once free from the axial bundle, the protoxylem strand of the trace begins to elongate tangentially, and bifurcates a short distance above (Fig. 6A, a). Each of the two traces diverges at a different level (Plate III, 1-3; Fig. 6A), and this difference is reflected in subsequent divisions of the protoxylem strands and of the traces as they proliferate in the cortex (Fig. 6A). At levels of divergence from axial bundles the traces are roughly circular in section and apparently contain both secondary xylem and phloem (Plate III, 1-3; Plate IV, 2, 3) which are lost distally (Plate IV, 4). Through their course in the cortex, the traces become elongate, as seen in transverse sections, then curved, with the inner, medial ends directed toward each other (Fig. 6A). Protoxylem strands increase in number and prior to entering the petiole base each trace produces a vascular bundle from its inner (medial) end followed by division of the outer (i.e., lateral) bundles to form a petiolar vascular supply of 6 bundles (Plate IV, 4; Fig. 6A, $d-g$ ). These become arranged in a $\mathrm{C}$-shaped pattern with the open side of the $\mathrm{C}$ directed toward the center of the stem (Plate I, I: Plate IV, 4; Fig.1D; Fig. 6A). An identical pattern characterizes specimen 41246 (the lectotype; Fig. 1A).

The cylinder of secondary xylem, $18 \mathrm{~mm}$ in diameter. consists entirely of tracheids and rays (Plate II, 1; Plate IV, 1). There is no evidence of growth layers. Tracheids range in radial dimensions of from $36-108 \mu \mathrm{m}$, most commonly 50-68 $\mu \mathrm{m}$. In tangential dimensions they exhibit a range of $30-72 \mu \mathrm{m}$, with a mean of $52 \mu \mathrm{m}$. Rays are commonly dilated at both inner and outer margins of the secondary vascular cylinder (Plate III; Plate IV, I; Plate V, I). Ray width (measured midway between inner and outer ends) varies from $1-12$ cells and $24-162 \mu \mathrm{m}$ with a mean width of $60 \mu \mathrm{m}$. Ray parenchyma cells are $12-36$ (mean $=$ 24) $\mu \mathrm{m}$ in tangential width. In radial dimension they vary from $67-137($ mean $=104) \mu \mathrm{m}$.

This specimen also provides the basis for interpreting the tissue enclosing the secondary xylem (Plate I, 1; Plate II, 1; Plate III; Plate V). Read (1936b) interpreted the phloem to occupy a zone in which he also included, but did not describe, what he called pericycle. He observed, and we 
corroborate, that vascular rays extend into, possibly through, the phloem (Plate V, 1-3), thus providing evidence of its derivation from the vascular cambium. Unfortunately, the regions between rays, that we believe were occupied in life by sieve cells and possibly associated parenchyma cells, are now largely empty cavities, the cells not having been preserved (Plate V, 1, 3). Of interest, however, is a zone of tissue immediately peripheral to this region, the so-called pericycle of Read (1936b) (Plate III; Plate V). Cells of this zone are polygonal in transverse configuration, measure 52-110 (mean $=70) \mu \mathrm{m}$, tending in the areas opposite vascular rays to be somewhat radially extended (Plate $\mathrm{V}, 1)$. In fact, the ray tissue merges imperceptibly into this zone of cells with absolutely no evidence of any boundary between (Plate V, 1-3). Differentiated within this zone, about midway between its inner and outer boundaries, and often opposite the ends of rays, are numerous, small clusters of very thin-walled cells, $104-160 \mu \mathrm{m}$ in diameter, which resemble to some extent the "nests of sclerotic cells" in the cortex (Plate II, 1; Plate III, 3; Plate V, 1-3, at arrows). The cells of these clusters measure $40-70 \mu \mathrm{m}$ in transverse dimensions. At the periphery of this zone of parenchyma are tangentially aligned groups of relatively thickwalled cells which may represent primary phloem sclerenchyma (Plate V, 2, 3 above black triangles).

The cortex of this specimen, like that of other specimens of Diichnia, is characterized, peripherally by a sparganum cortex, typical of many early pteridosperms, consisting of longitudinally anastomosing strands of thick-walled fibers interspersed with parenchyma (Plate I, 1; Plate IV, 3). The fibers vary in diameter from $65-112 \mu \mathrm{m}$ with a mean diameter of $88 \mu \mathrm{m}$. The parenchyma cells between strands of fibers have diameters of from 103-282 $($ mean $=154) \mu \mathrm{m}$. Scattered within the parenchymatous ground tissue, primarily to the inside of the sparganum region, are spherical to ovoid masses of cells (Plate IV, 3, 4, arrows), $300-940($ mean $=540) \mu \mathrm{m}$ in diameter. Centrally these masses contain isodiametric cells 56-108 (mean $=82$ ) $\mu \mathrm{m}$ in diameter. Radiating from these central clusters of cells are elongate cells 170-394 $($ mean $=266) \mu \mathrm{m}$ long and 56-94 (mean = 77) $\mu \mathrm{m}$ wide. The nature of these spherical masses poses an interesting problem. Read (1936b) described them as "cavities of apparently lysigenous origin". He suggested that they were "apparently secretory, although no evidence of gum was observed". He stated further that "similar canals lie in the parenchymatous portion of the mixed pith". The regions that Read called secretory cavities or "canals" have been commonly called sclerotic nests (or clusters) in other taxa, e.g. Calamopitys (Galtier and Meyer-Berthaud, 1989), Galtiera (Beck and Stein, 1987), and Stenomyelon (Kidston and Gwynne-Vaughan, 1912). In the specimens of Diichnia that Read described, some of these masses of cells had apparently fallen out of the sections during preparation leaving the cavities that Read mentioned. Where the cells remain, however, their walls are frequently, but not always, thin. This is true also of comparable clusters in specimen 356463 and all other specimens we have studied. In no sense are these structures canals as suggested by Read, nor have we observed them in the pith (see below). We do not know their function although the cells of similar masses in species of Calamopitys in Galtier's collection seem to contain dark contents. Thus, they may have been sites of storage or of secretion.

The inner cortex is commonly compressed so that in transverse sections the long axis of the cells seems to be oriented tangentially (Plate I, 1; Plate IV, 2, 3). We believe this compression resulted largely from expansion of secondary vascular tissues, and to a lesser extent from cell proliferation in the parenchyma zone surrounding the phloem. It is surprising, however, that in some regions of this specimen, the tissue immediately peripheral to the parenchyma zone, and between it and the compressed cortical region, appears uncompressed, even loose with large intercellular spaces (Plate V, 4). We are at a loss to explain why this tissue was not also compressed, and suspect that its appearance might be an artifact of preservation.

We are unable to explain Read's statement (1936b) concerning the presence in the pith of "canals which appear to be of secretory function and lysigenous origin". There are, however, very large, thin-walled cells in the pith of specimens 41246 and 356463 (Plate I, 2, 3) that Read may have mistaken for canals. Since none of these cells 


\section{PLATE I}

Diichnia kentuckiensis Read.

1. Transverse section of stem providing an overview of the various tissue regions and the petiolar vascular supply. USNM 356463, slide $1 . \times 3.5$

2-5. Transverse sections showing details of the pith. Note especially thick-walled tracheid-like cells of varying sizes and some large thin-walled cells. USNM 356463 , slides $1,4,4$, and 2 , respectively. $\times 42$.

PLATE II (see p. 8)

Diichnia kentuckiensis Read.

1. Transverse section illustrating the pith, primary vascular system, and secondary vascular cylinder bounded by a thick zone of parenchyma. The secondary phloem is a narrow cylinder between the secondary xylem and peripheral parenchyma zone, characterized by small cavities which, in life, contained the conducting elements. Note the five conspicuous axial bundles and an accessory strand (arrow). USNM 356463, slide $1 . \times 7.8$.

2, 3. Detail of two axial bundles from 1. Protoxylem strands are indicated by arrows in 2 . USNM 356463, slide $1 . \times 42$.

PLATE III (see p. 9)

Diichnia kentuckiensis Read.

1-3. Transverse views, in ascending order, illustrating the departure of a pair of leaf traces which, together, develop into the vascular supply of a single leaf. Note the asymmetry in level of departure of the traces. USNM 356463, slides 2 , 4, and 7, respectively. $\times 10$.

PLATE IV (see p. 10)

Diichnia kentuckiensis Read.

1. Transverse section of secondary xylem illustrating the conspicuous dilation of rays near the boundary of the pith. Note also the accessory bundle (shown also, in a different section, in Plate II, 1) which is in tracheary continuity with the secondary xylem. USNM 356463 , slide $2 . \times 42$.

2. Transverse view of a leaf trace in the cortex, proximal to a level of division. Note the secondary xylem and the conspicuous phloem region. The compressed cortical tissue to the inside of this trace may have resulted largely from the production of secondary vascular tissues. USNM 356463 , slide $4 . \times 17$.

3. Transverse section of a region of cortex containing a pair of leaf traces. As these traces traverse the cortex, they lose the accompanying secondary xylem and divide to form the petiolar vascular supply as shown in 4 . Note the sparganum outer cortex and a sclerotic cluster (arrow). Also note the compressed cortical parencyma between the traces and the peripheral parenchyma zone. USNM 356463, slide 7. $\times 5.6$.

4. Transverse view of cortex showing the petiolar vascular supply at a level at which secondary xylem no longer accompanies the traces and they have begun to divide. Note the medial separation of the first bundle from each trace; also the sclerotic clusters (arrows). USNM 356463, slide $1 . \times 5.6$.

\section{PLATE V (see p. 11)}

Diichnia kentuckiensis Read.

1. Transverse section showing the secondary phloem region and the peripheral parenchyma zone. The phloem region is clearly indicated by the dilated phloem rays which merge imperceptively with the peripheral parenchyma zone. Phloem conducting cells are not preserved. Note the cavities (arrows) that contained clusters of thin-walled cells (see 2). USNM 356463, slide $1 . \times 40$.

2. Transverse view of peripheral parenchyma zone containing a row of clusters of thin-walled cells similar to those that comprise the central regions of the sclerotic clusters that occur in the cortex. Note also the small, tangentially oriented cluster of thickwalled cells near the outer edge of this zone (black triangle) which may be primary phloem sclerenchyma; cells of the same type are also shown in 3 . USNM 356463, slide $7 . \times 40$.

3. Transverse view of peripheral parenchyma zone illustrating a row of clusters of sclerenchyma cells near its outer margin (black triangles). Note also the poorly preserved phloem region and the cavity (arrow) which contained cells like those denoted by arrows in 2. USNM 356463, slide 2. $\times 40$.

4. Transverse section showing a region of inner cortex, just outside the peripheral parenchyma zone, containing loosely aggregated cells. USNM 356463, slide 7. $\times 40$. 


\section{PLATE I}
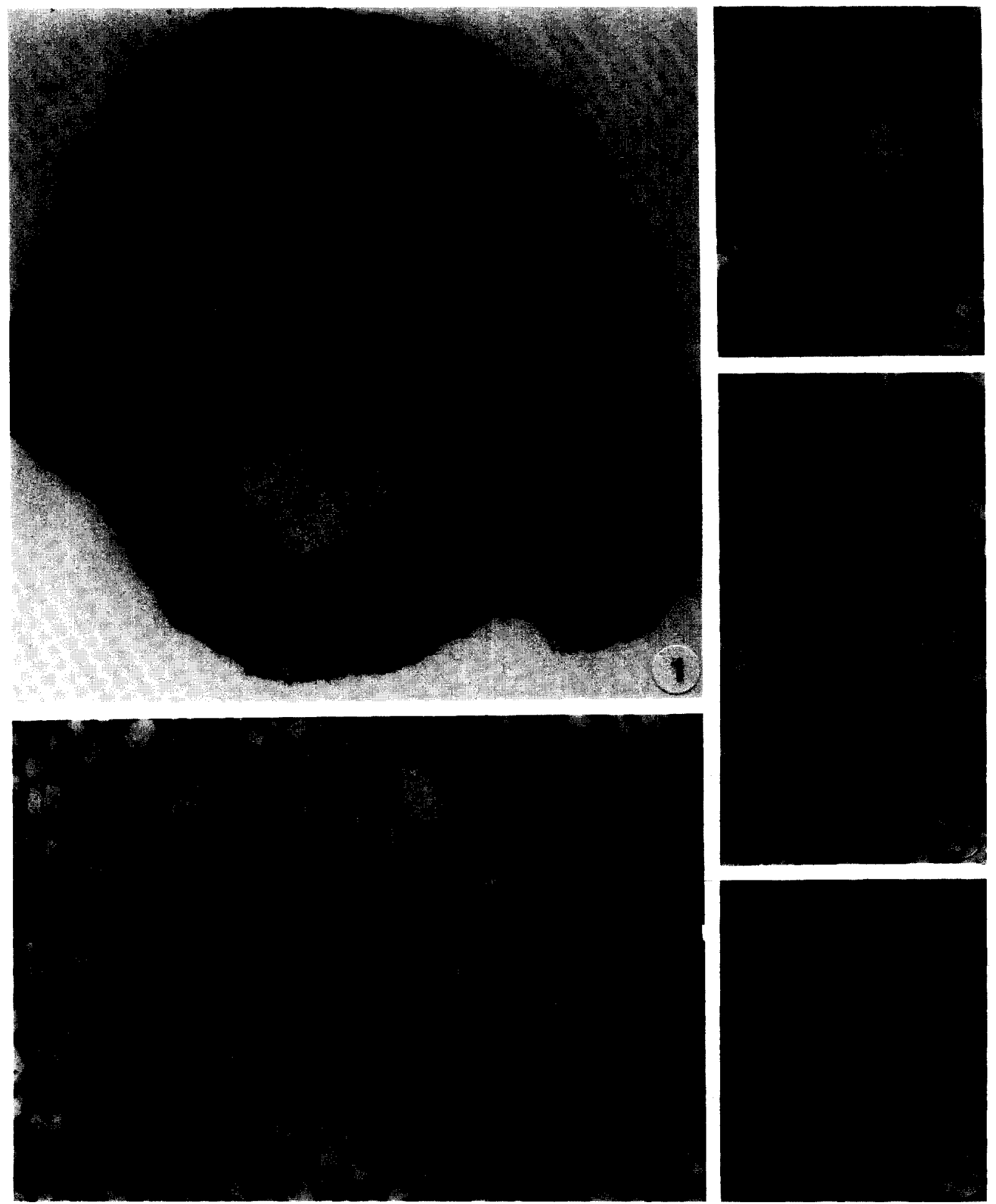


\section{PLATE II}

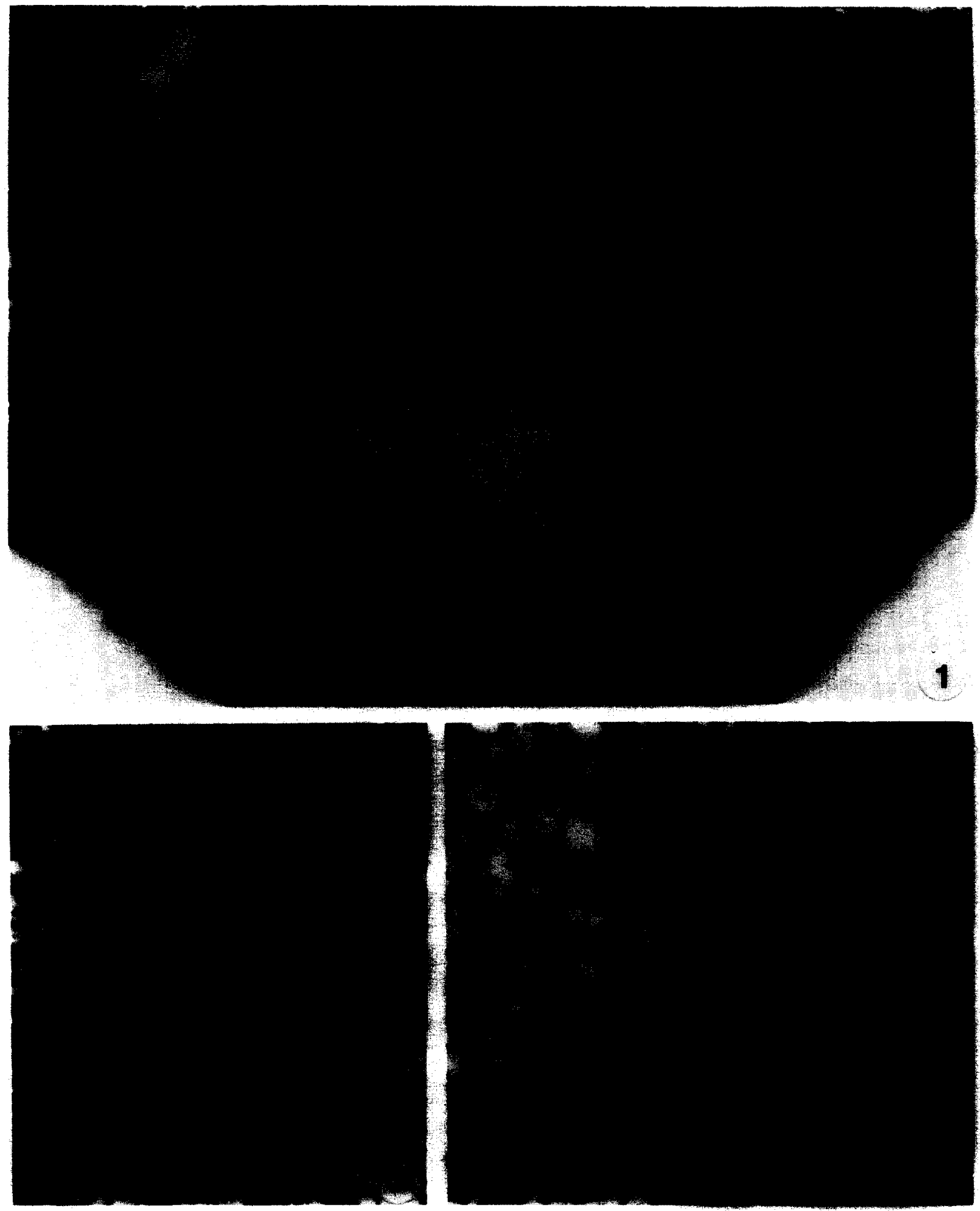

(for description see p. 6) 
PLATE III
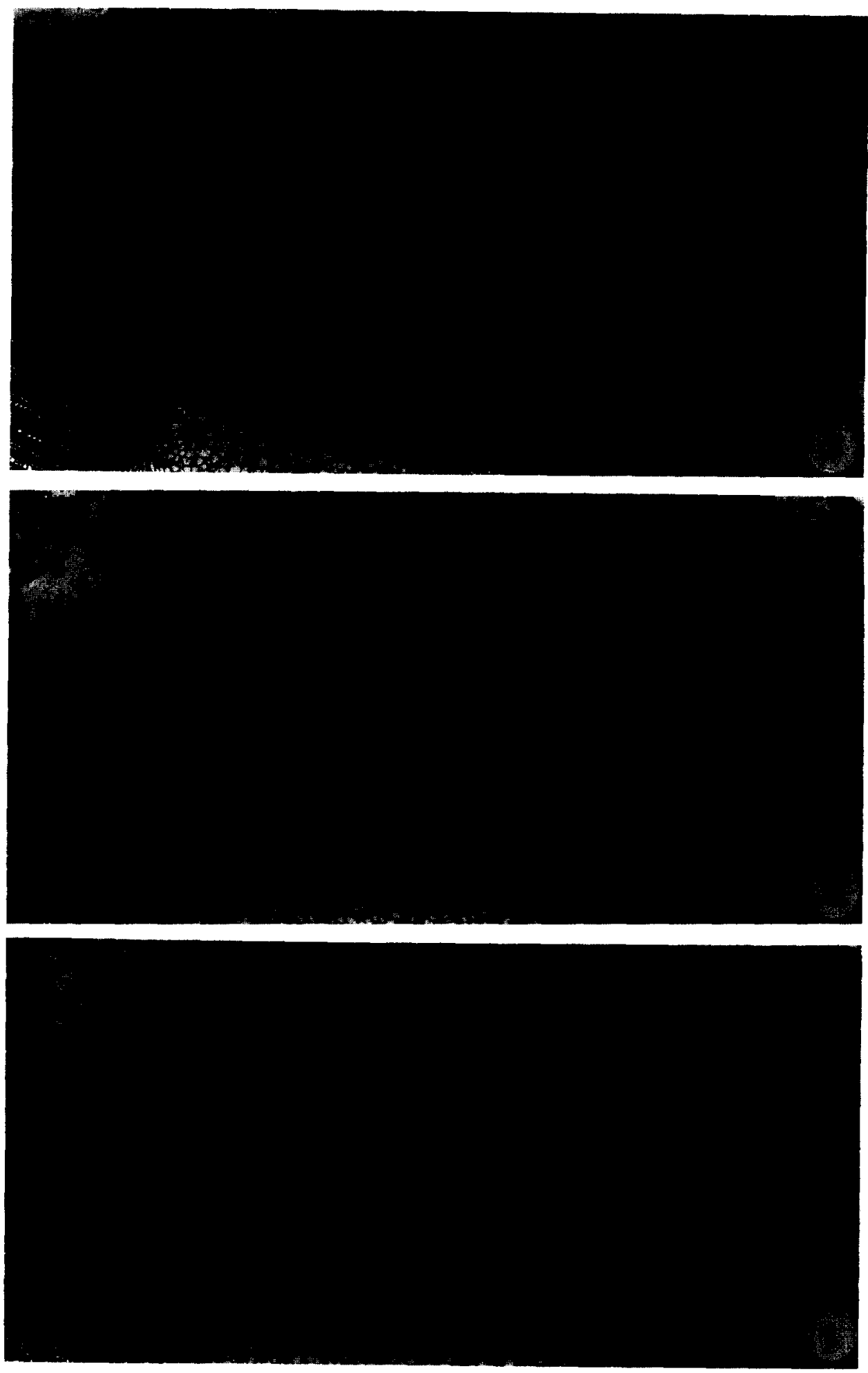

(for description see p. 6) 


\section{PLATE IV}
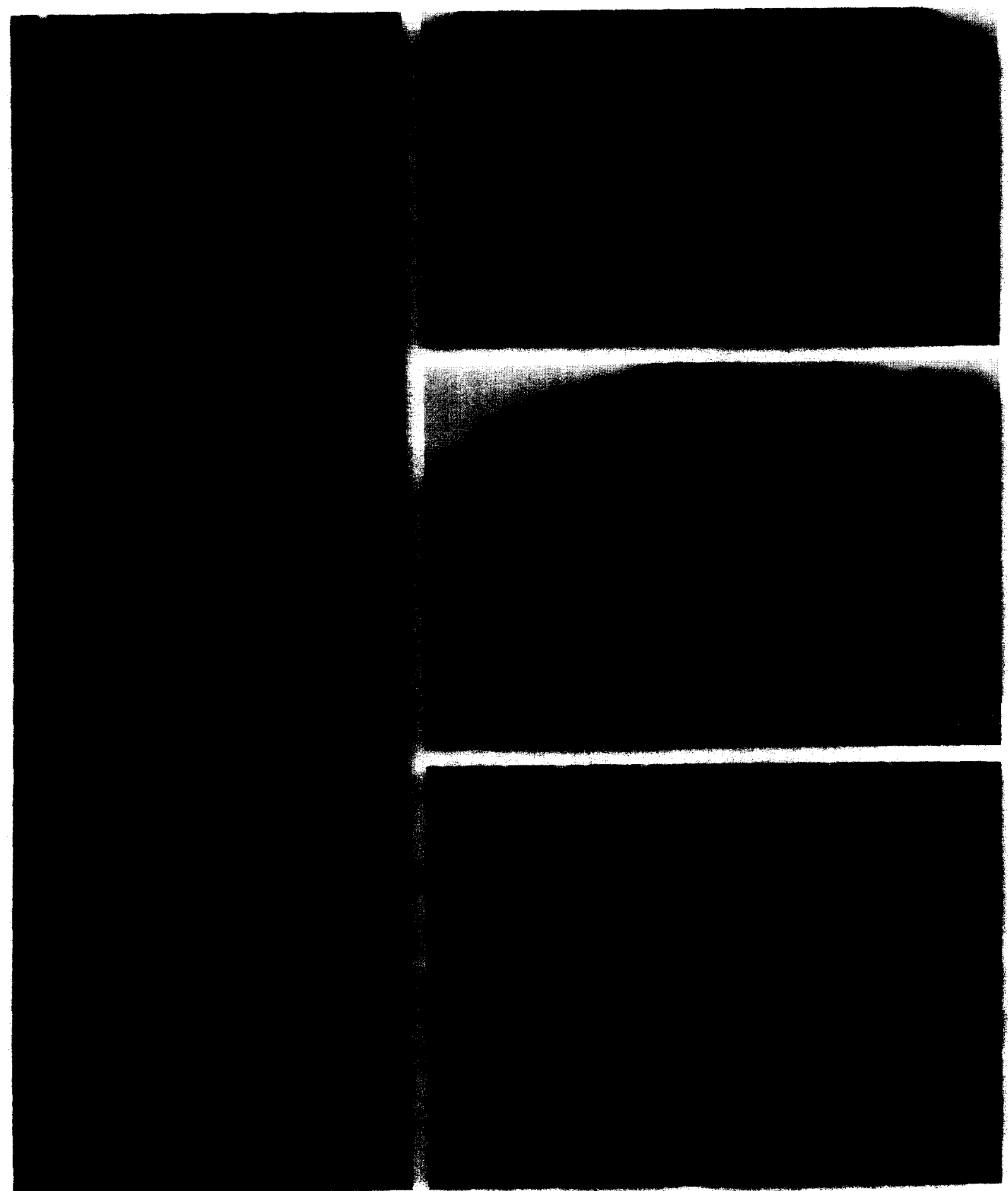

(for description see p. 6 ) 


\section{PLATE V}
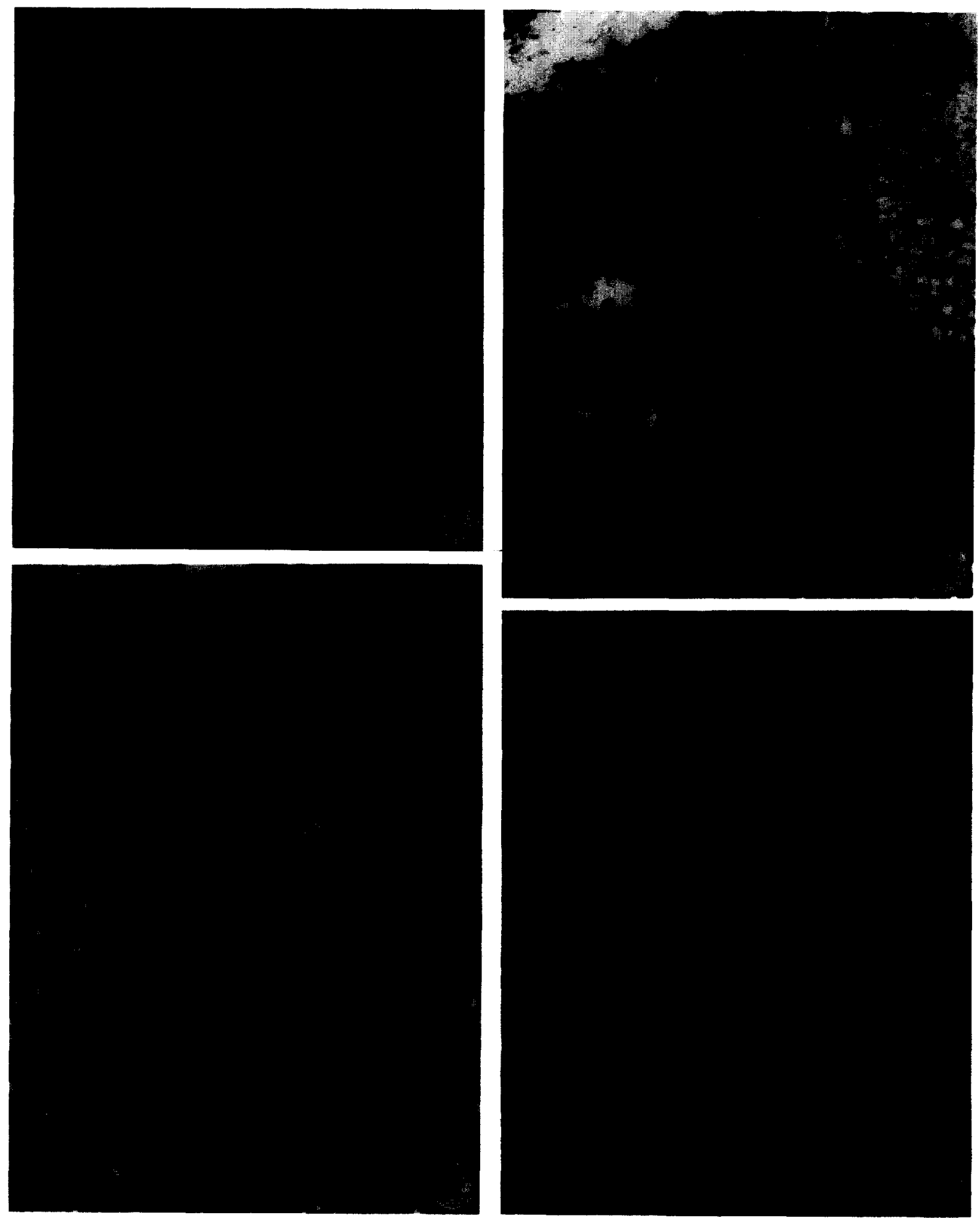
can be traced over the distance between two consecutive sections in either specimen, it is clear that they are not canals. We are unable to suggest their likely function.

Following descriptions below of previously undescribed specimens, we shall present additional information on nodal and other aspects of stelar anatomy as well as the petiolar vascular supply.

\section{Specimen USNM 41247}

This specimen (Fig. 1B; Plate VI, 1), identified by Read as Diichnia on the basis of two sections, has all of the characteristics of specimen 41246, described by Read (1936b). However, the axis, with transverse dimensions of $20 \times 18 \mathrm{~mm}$, is only about one half the size of this latter specimen (Fig. IA, B). The petiolar vascular supply originates in the same way, i.e. as a pair of bundles, each bundle diverging from an adjacent axial bundle (Figs. 1B, 2B 6B, a), and proliferation of the pair of bundles in the cortex is also identical (Fig. 6B $a-h$ ), but the tangential span of the petiolar vascular supply of 6 vascular bundles is only
$5 \mathrm{~mm}$ compared with $12 \mathrm{~mm}$ in the lectotype, and there are no secondary vascular tissues associated with the traces in the cortex (Plate VI, 1; Plate VIII, 1; Fig. 6B). The primary vascular system is also essentially identical with that of specimen 41246 , except that vascular bundles are commonly in contact with the secondary xylem (Plate VI, 2). As in specimen 41246 , there are two or three small bundles that intervene between pairs of axial bundles (Plate VI, 2, arrow; Figs. 1B, 2A, B). The most conspicuous difference is the nature of the pith, $4.0 \times 2.6 \mathrm{~mm}$ in transverse dimensions, in which is located, centrally, a mass of tracheid-like cells (Plate VI, 1, 2; Plate VIII, 5). These cells measure $37-150 \mu \mathrm{m}($ mean $=86 \mu \mathrm{m})$. Pith parenchyma cells are $26-170($ mean $=95) \mu \mathrm{m}$ in diameter with an occasional cell reaching $210 \mu \mathrm{m}$ in diameter and $40-140 \mu \mathrm{m}$ in height. Radiating from the mass of tracheids are ribs of this tissue that extend toward, or to, the five axial bundles (Plate VI, 2: Fig. 7). When this central tracheary tissue and the remainder of the primary vascular system are outlined in a series of drawings of serial sections. and the drawings stacked, one obtains the appear-
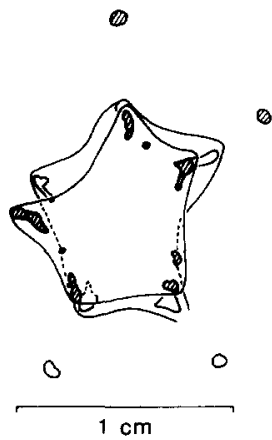

A

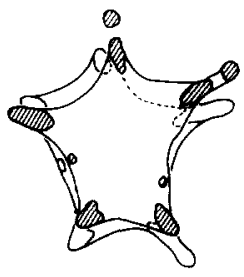

B

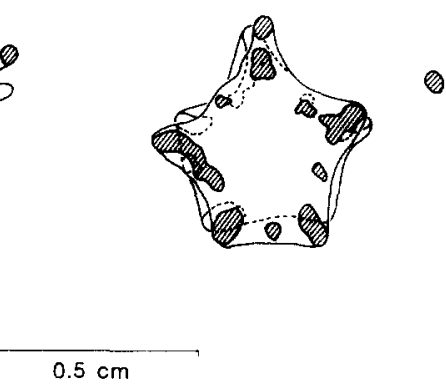

$0.5 \mathrm{~cm}$

C

Fig. 2. Superposed sections (most proximal below, distal above) of Diichnia kentuckiensis (A, B) and D. readii (C), showing reduction in distance between axial bundles near levels at which the pair of traces to a single leaf originate. A. USNM 41246. B. 41247 . C. 172325 .

\section{PLATE VI}

Diichnia kentuckiensis Read

1. Transverse section providing a general view of the tissue regions and histological characteristics of the stem. USNM 41247 , slide CB9. $\times 6.45$.

2. Enlargement of pith and stelar region of stem illustrated in 1. Note the five axial bundles and two conspicuous accessory bundles (large arrows). Slender arrow denotes the protoxylem region of an accessory bundle (enlarged in Plate VIII, 4) just proximal to the level of its separation from an axial bundle. Note also the prominent tracheary tissue in the pith that is continuous with the axial bundle at lower left. USNM 41247, slide CB9. $\times 22$. 


\section{PLATE VI}
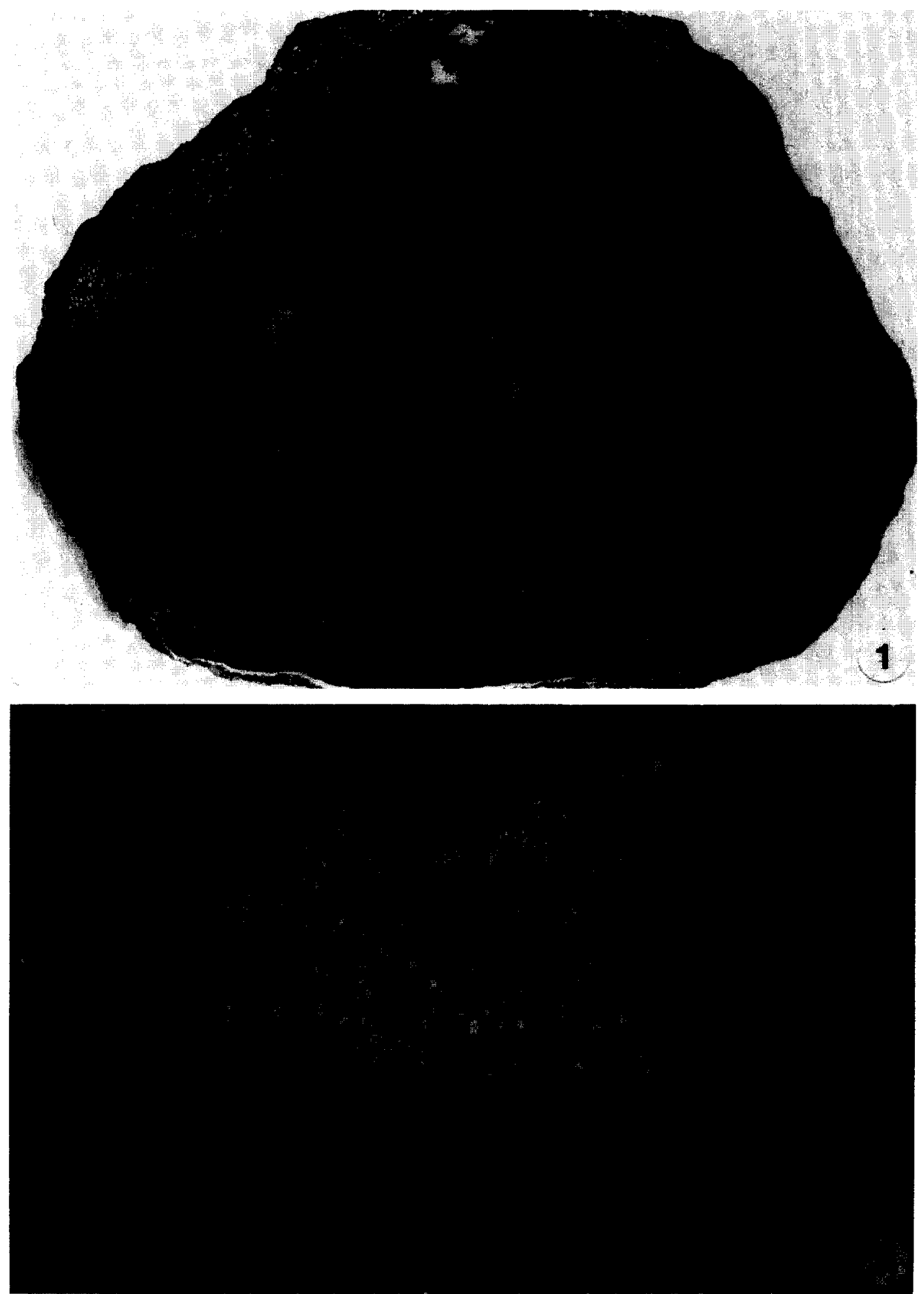
ance, essentially, of a 5-ribbed protostele (Fig. 7). Longitudinal sections through this tissue reveal it to contain elongate tracheid-like cells, some with truncate ends (Plate VIII, 5). No pitting is visible in the walls of these cells, but one is also unable to observe pits in face view in tracheids of the secondary xylem - an unfortunate result of the preservation of specimens in the phosphatic facies of the New Albany shale. Similar tissue comprised of cells with circular bordered pits is common in some small specimens of Calamopitys in Galtier's collection.

The functional significance of the central tracheary tissue is not clear at present. We suggest that it may be analogous to tissue of similar anatomy that occupies the pith region of small stems of several conifer species that we have observed. Morphometry and possible phylogenetic significance of this tissue, if any, will be discussed in a future paper.

Metaxylem tracheids in axial bundles are 26-120 $($ mean $=82) \mu \mathrm{m}$ in diameter with an occasional cell reaching a maximum diameter of $140 \mu \mathrm{m}$. Metaxylem tracheids in leaf traces measure $26-90 \mu \mathrm{m}$ in diameter. Protoxylem tracheids are $15-25 \mu \mathrm{m}$ in diameter.

A feature of potential importance in interpreting the stelar anatomy of the genus is the manner of production of the small "intervening" bundles which we shall henceforth call accessory bundles following Beck (1970). At a level above that at which a leaf trace diverges, a strand of primary xylem extends tangentially from the axial bundle. Associated protoxylem is inconspicuous since initially it is not encompassed by metaxylem (Plate VI, 2, small arrow; Plate VIII, 4, arrow). At successively higher levels, the accessory bundle becomes free of the axial bundle and conspicuously mesarch. Two other comparable accessory strands persist through the entire series of sections (Plate VI, 2, large arrows).

Secondary xylem appears well preserved in transverse sections (Plate VII, 1, 2) but detail is lacking in longitudinal sections (Plate VII, 3,4). The cylinder has a thickness of $3.1 \mathrm{~mm}$ and a diameter of $10 \mathrm{~mm}$. Tracheids vary in radial dimension from $26-102 \mu \mathrm{m}$, commonly $43-74 \mu \mathrm{m}$. They vary in tangential dimensions from $26-88 \mu \mathrm{m}$, commonly $39-70 \mu \mathrm{m}$. Tracheid pitting is rarely visible in face view, but sectional views of bordered pit pairs are occasionally visible in tangential sections (Plate VII, 4). Pits, up to 8 rows, apparently occur only in the radial walls. Pits are very small, circular to elliptical, and $12-16 \mu \mathrm{m}$ in diameter. Rays vary from narrow to very broad $-1-8$ cell rows: 18-208 (mean $=64) \mu \mathrm{m}-$ and are very high (greater than $2.7 \mathrm{~mm}$ ) (Plate VII, 4). Ray cells in radial view have the generally rectangular shape of those typical of gymnosperms (Plate VII, 3). They measure $18-30($ mean $=22) \mu \mathrm{m}$ in tangential width, $104-160 \mu \mathrm{m}$ in radial dimension, and $24-30$ (mean $=30$ ) $\mu \mathrm{m}$ in height.

Our specimens of Diichnia are not characterized by consistent growth layers. However, some environmental fluctuation, perhaps of temperature or moisture availability, is reflected in an increment of tracheids of small radial dimension in specimen 41247 (Plate VII, 1, 2). This zone forms a continuous cylinder.

The secondary phloem, like that of the lectotype (41246), is poorly preserved. Regions in which conducting cells were apparently contained are largely empty cavities. Rays, somewhat dilated in the phloem, extend into and end imperceptively in a poorly preserved peripheral zone of parenchyma identical to that of the lectotype (41246) and

\section{PLATE VII}

Diichnia kentuckiensis Read.

1. Transverse section of secondary xylem showing tracheids and predominantly multiseriate rays, most of which gradually broaden toward the periphery. Note also apparent boundary of a growth layer near outer margin. USNM 41247, slide CB9. $\times 22$.

2. Detail showing tracheids with narrow radial dimensions marking the boundary of an apparent growth layer. USNM 41247. slide CB9. $\times 130$.

3. Radial section of secondary xylem. USNM 41247, slide $24 / 11 . \times 130$.

4. Tangential section of secondary xylem. Note tall uniseriate, biseriate and multiseriate rays, and sectional views of closely-spaced. bordered pit pairs in the radial walls of contiguous tracheids. USNM 41247, slide 24/17. $\times 130$. 


\section{PLATE VII}
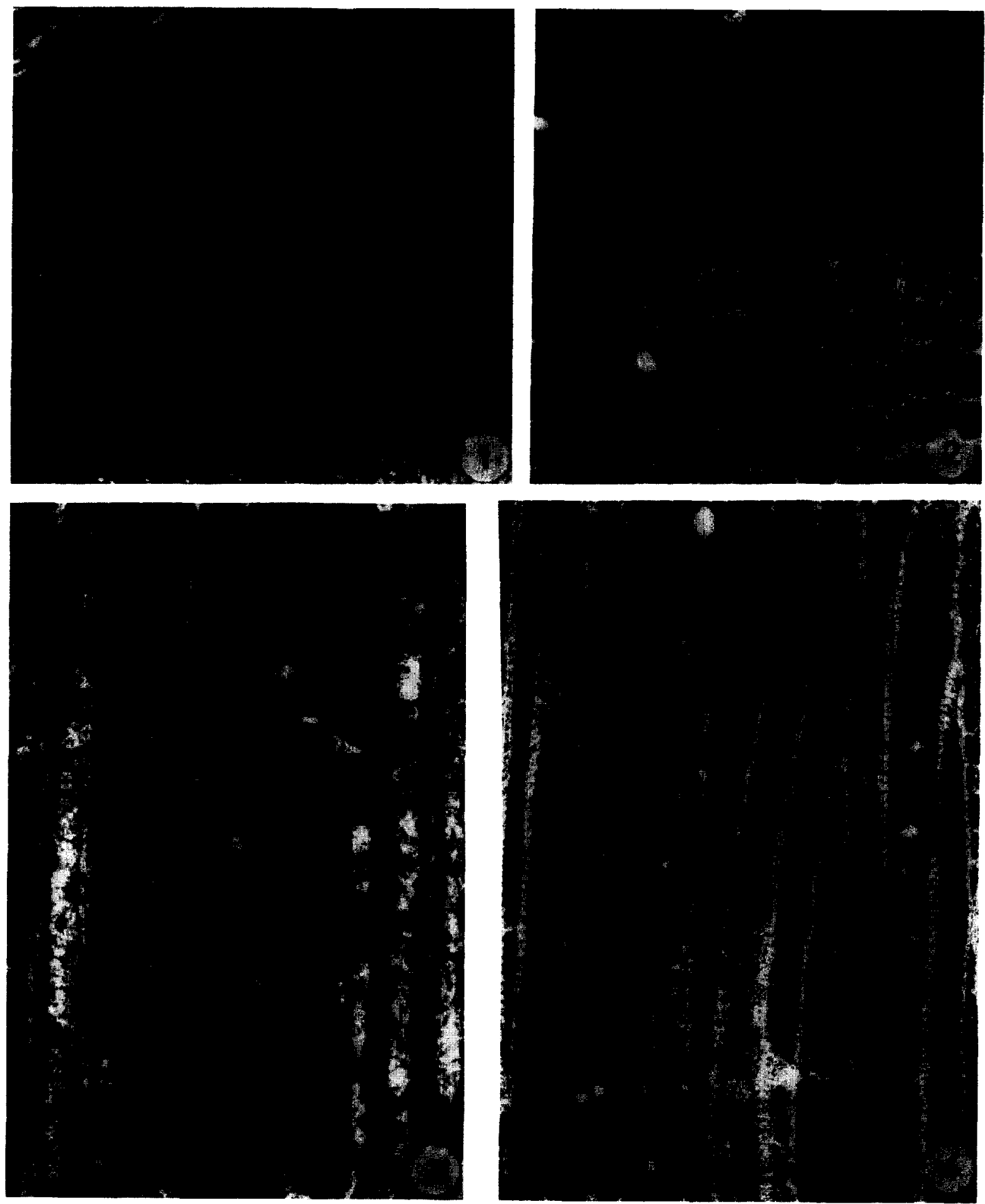
specimen 356463. As in these latter specimens, this zone of parenchyma contains essentially spherical masses of thin-walled cells that resemble those of the central core of cortical "sclerotic clusters". The spherical masses vary in diameter from $150-200 \mu \mathrm{m}$. Parenchyma cells of the peripheral zone measure $40-60 \mu \mathrm{m}$ in diameter.

As in the lectotype (41246) the cortex is a complex tissue region (Plate VI, 1; Plate VIII, 1). Parenchyma cells of the inner cortex have radial dimensions of 52-104 $\mu \mathrm{m}$, tangential dimensions of 104-260 $\mu \mathrm{m}$, and a height (longitudinal dimension) of 52-104 $\mu \mathrm{m}$. Scattered sclerotic nests (Plate VIII, 1, arrows) vary in both radial and tangential dimensions from $244-800 \mu \mathrm{m}$, and have a height of $220 \mu \mathrm{m}$. The central cells of sclerotic nests vary in diameter from $51-84($ mean $=68) \mu \mathrm{m}$. The radiating peripheral cells of these structures are $130-360($ mean $=214) \mu \mathrm{m}$ long and $37-65($ mean $=$ 52) $\mu \mathrm{m}$ wide. The outer cortex is composed of radially oriented plates of thick-walled fibers between which are regions of parenchyma, the cells of which are commonly extended tangentially as viewed in transverse section (Plate VI, 1). The fibers are 50-70 $($ mean $=60) \mu \mathrm{m}$ in diameter, and the intervening parenchyma cells, 70-160 (mean = 110) $\mu \mathrm{m}$ long in transverse section.

\section{Specimen 172325}

This specimen (Plate IX, 1; Fig. 1C) differs from the others described in the manner of division of the petiolar bundles, and in certain details of stelar architecture. In other features including leaf trace divergence, details of the secondary phloem region and the encompassing secondary parenchyma as well as the cortex, this specimen is similar to those previously described. One minor variation in the cortex is the great number of "sclerotic nests" which appear to be comprised of cells with variably thick walls (Plate IX, 1; Plate XI, 2, 3, 5; Plate XII, 4). We assign it with confidence to Diichnia because, as is characteristic of the genus, its leaf vascular supply is derived from two traces that diverge from different, adjacent axial bundles (Plate XI, 1; Fig. 3A, B, C).

Whereas in the lectotype and specimen 41427 the division of the original pair of petiolar bundles first occurs from their inner (medial) ends as seen in transverse section, in this specimen branching begins from the outer (lateral) ends of the bundles (Plate XI, 2; Fig. 3C). The stele of this specimen differs in consisting of 10 vascular bundles, as seen in transverse section, five axial bundles and four or five accessory bundles more or less equally spaced around a 5-angled pith (Plate IX, 2: Figs. 2C, 3A). It should be noted also that tracheary tissue and parenchyma seem to be intermixed randomly in the pith (Plate IX, 2; Plate X, 1). Details of stelar architecture, including leaf trace divergence, of this and other specimens will be presented in the following section.

This stem measures about $20 \mathrm{~mm}$ in diameter. and has a pith (Plate IX, 1, 2) $3.6 \mathrm{~mm}$ across. Pith parenchyma cells vary in diameter from 38-150 (commonly $60-82$ ) $\mu \mathrm{m}$ and are $42-125 \mu \mathrm{m}$ high. Diameter of pith tracheids varies from 30-150 (commonly 50-66) $\mu \mathrm{m}$. Metaxylem tracheids in axial bundles measure 20-112 (commonly 60-70) $\mu \mathrm{m}$ in diameter whereas those in leaf traces are $26-108 \mu \mathrm{m}$ in diameter. The tangential width of the entire petiolar vascular supply (Plate XI, 2;

\section{PLATE VIII}

Diichnia kentuckiensis Read

1. Transverse section illustrating two traces just proximal to medial branching in the formation of the petiolar vascular supply Note also sclerotic clusters (arrows). USNM 41247, slide CB9. $\times 19$

2. Longitudinal section through fibers in the sparganum outer cortex. USNM 41247, slide $24 / 7 . \times 130$

3. Transverse section of the sparganum outer cortex showing strands of fibers and intervening parenchyma cells. USNM 41247. slide CB9. $\times 130$.

4. Transverse section of an axial bundle and the protoxylem of an incipient accessory bundle (arrow) proximal to the level of branching. This is an enlargement of the axial bundle and the incipient accessory bundle denoted by the slender arrow in Plate VIII. I. USNM 41247, slide CB5. $\times 130$.

5. Longitudinal section of tracheary tissue in the pith showing tracheids and associated parenchyma cells. USNM 41247. slide $24 / 11 . \times 130$ 


\section{PLATE VIII}
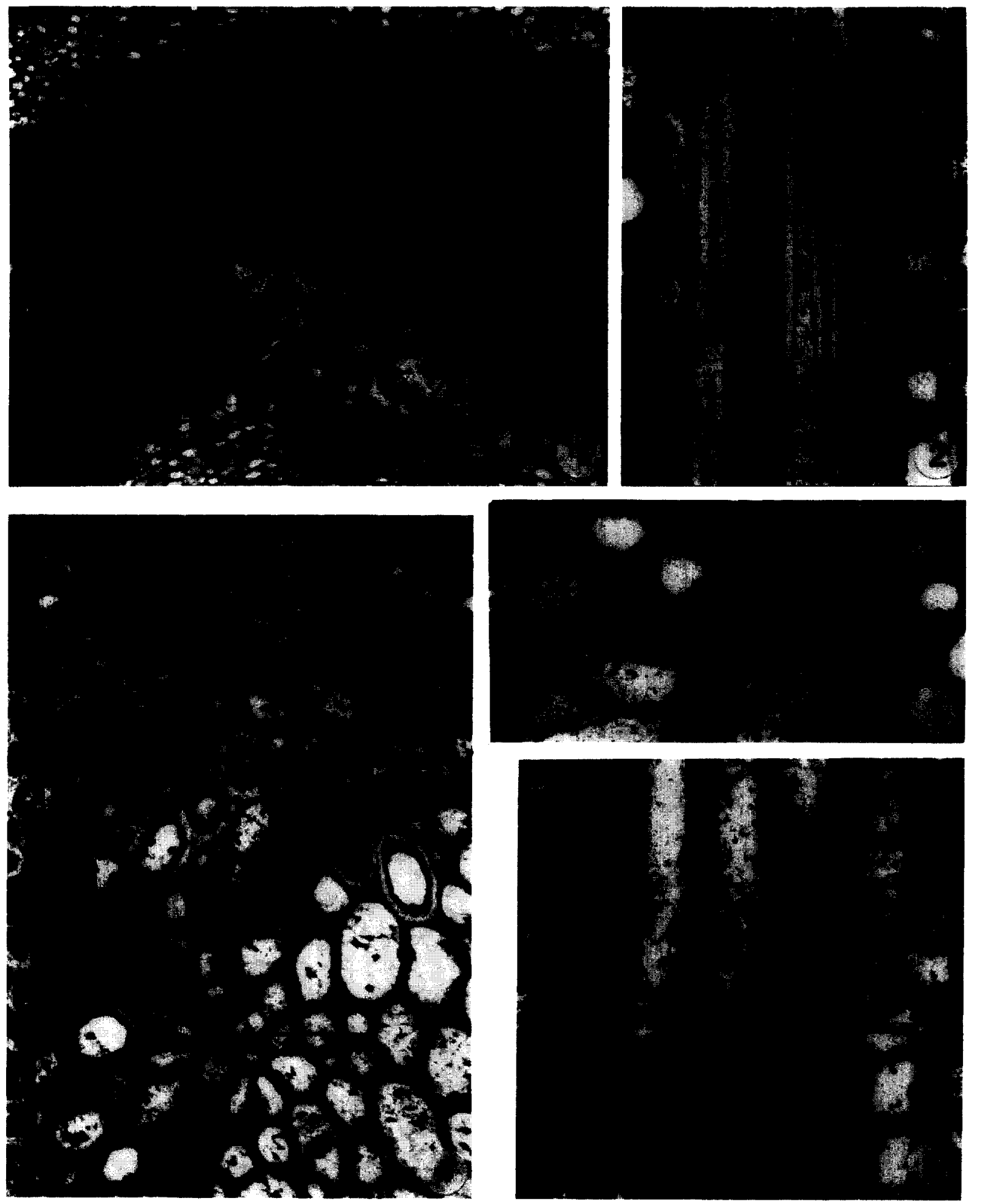

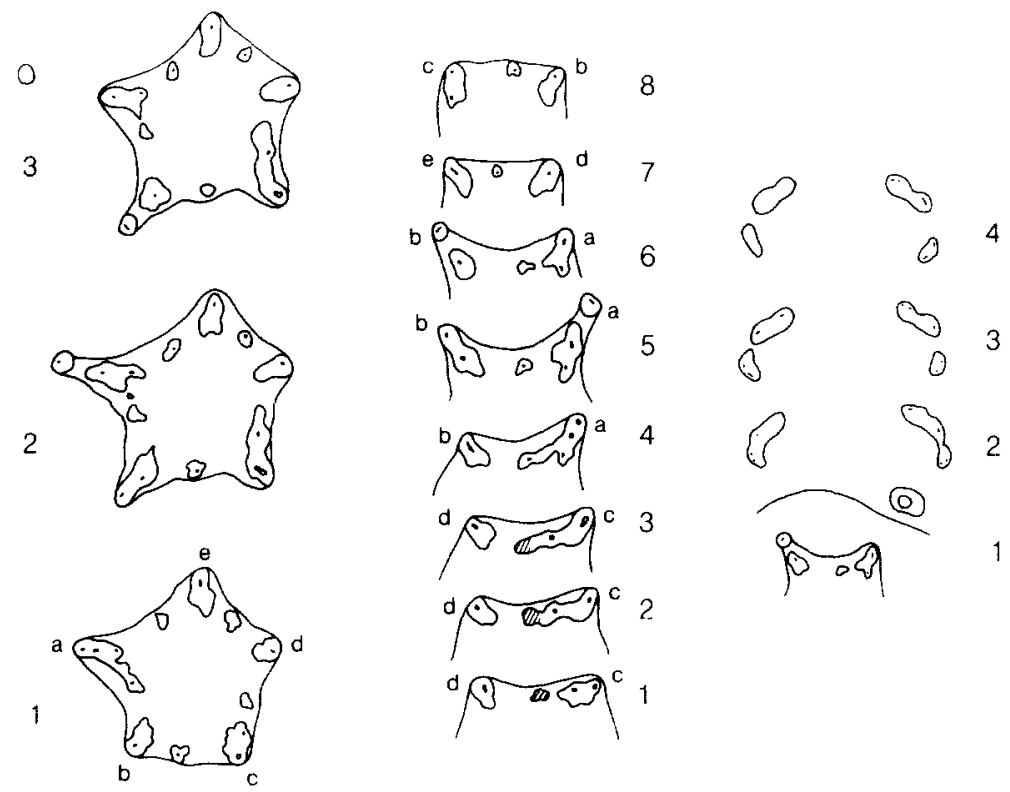

$0.5 \mathrm{~cm}$

B

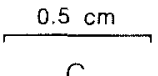

Fig. 3. Diichnia readii sp. nov. A. Parts of proximal, intermediate and distal sections showing pattern of vascular sympodia ( $a-\ell$ ), intervening accessory bundles and divergence of a pair of traces to a leaf. A, 1-3: USNM 172325: A, 1= sec. 26; A, 2= sec. 2: A, $3=\mathrm{sec}$. 1056. B. Camera lucida drawings illustrating fusion of an accessory bundle to and divergence from an axial bundle proximal to level of divergence of a leading trace: also divergence of the pair of traces from which the vasculature of a petiole originates, and the pattern of branching of protoxylem strands during these developmental events. Letters denote sympodia and correspond to those in Fig.3A and Fig.4B. B, 1-8: USNM 172325; B, 1 = sec. 26; B, 2=sec. 2; B, 3=sec. 1056; B, 4= sec. 26; B, 5=sec. 4; B, $6=\sec .1056 ; \mathrm{B}, 7=\mathrm{sec} .1056 ; \mathrm{B}, 8=\mathrm{sec}$. 26. C. Drawings showing branching of leaf traces in the formation of the petiolar vascular supply. C, 1-4: USNM 172325; C, I =sec. 1055; C, $2=\sec .26 ; \mathrm{C}, 3=\mathrm{sec} .12 ; \mathrm{C}, 4=\mathrm{sec} .2$.

Figs. 1C, 3C) is $7 \mathrm{~mm}$. The secondary xylem has a thickness of about $2.2 \mathrm{~mm}$ whereas the diameter of the secondary xylem cylinder (Plate IX, 1, 2) is $7.5 \mathrm{~mm}$. Secondary xylem tracheids measure $20-80$ (commonly $42-52) \mu \mathrm{m}$ in radial dimension and $20-72$ (mean $=40) \mu \mathrm{m}$ in tangential dimension. Their radial walls contain up to 6 rows of circular to elliptical bordered pits (Plate X, 6) about $10 \mu \mathrm{m}$ in diameter. Rays (Plate IX, 2; Plate X, 4, 5) are $1-8$ cells and $18-150($ mean $=60) \mu \mathrm{m}$ wide, and more than one millimeter high. (A more exact estimation of ray height could not be made since longitudinal sections were cut from transverse segments only about $1 \mathrm{~mm}$ thick.) Ray parenchyma cells (Plate $X, 4,5$ ) are $52-104 \mu \mathrm{m}$ in radial and $14-30 \mu \mathrm{m}$ in tangential dimensions, and $10-40$ (commonly 30 ) $\mu \mathrm{m}$ high. The secondary phloem (Plate XI, 4) is very poorly preserved, but appears similar to that of the other specimens described. Rays, dilated beyond their width in the secondary

\section{PLATE IX}

\section{Diichnia readii sp. nov.}

1. Transverse section of stem illustrating tissue regions and general histological features. USNM 172325, slide $1055 . \times 5.2$.

2. Pith, primary vascular system and secondary xylem in transverse section. Note five axial bundles and five intervening accessory bundles, one of which (arrow) is connected to an axial bundle. Compare with Fig.3A, 1-3). USNM 172325, slide $23 . \times 13.4$.

3-6. Transverse views from three different slides illustrating the fusion to and departure from an axial bundle of an accessory bundle proximal to the level of trace divergence from that axial bundle. USNM 172325, slides 20, 14, 14, and 3, respectively. $\times 20$. 

xylem merge with a peripheral zone of parenchyma (Plate IX, 1; Plate XI, 4, 5; Plate XII, 1, 2). To the inside of this zone and between the rays are cavities which, presumably, in life contained the conducting elements of the phloem (Plate XI, 4). The parenchyma cells of the peripheral parenchyma zone vary in diameter from 40-104 $\mu \mathrm{m}$ and from $50-90 \mu \mathrm{m}$ in height. In some regions they are radially elongate at the periphery of the zone where they appear to be in continuity with radiating cells of the sclerotic nests (Plate XI, 5; Plate XII, 1, 2). Within the peripheral parenchyma zone are irregularly oval to circular clusters of cells $(65-200 \mu \mathrm{m}$ in diameter) commonly represented by cavities located about midway between its inner and outer boundaries (Plate X, 7; Plate XI, 4). As in other specimens, these clusters of cells are similar to the central regions of "sclerotic clusters". The cortex contains many "sclerotic nests" embedded in a parenchyma ground tissue (Plate X, 3; Plate XI, 2, 5; Plate XII, 1, 2, 4). Cells of the ground tissue are $80-260 \mu \mathrm{m}$ in diameter and $35-80 \mu \mathrm{m}$ high. The sclerotic nests measure 245-1034 (mean= $600) \mu \mathrm{m}$ in diameter but only $150-200 \mu \mathrm{m}$ in height (longitudinal thickness). Thus, in three dimensions they can be envisioned as relatively flat disk-shaped regions (Plate $X, 3$ ) unlike the more spherical regions in specimens 41246 and 356463 . The central

\section{PLATE X}

Diichnia readii $\mathrm{sp}$. nov.

1. Longitudinal section through the pith showing scattered tracheid-like cells. USNM 172325 , slide 7.5 . $\times 38$.

2. Longitudinal section through sparganum outer cortex showing a strand of fibers and outer cortical parenchyma. USNM 172325. slide 7.2. $\times 46$.

3. Sclerotic cluster shown in longitudinal section illustrating its flattened form. USNM 172325. slide $7.4 . \times 38$.

4. Radial section of secondary xylem illustrating tracheids and a tall ray. USNM 172325, slide 7.6. $\times 136$.

5. Tangential section of secondary xylem showing uniseriate and broad multiseriate rays. USNM 172325, slide $7.9 . \times 136$.

6. Oblique longitudinal section showing multiseriate bordered pits in tracheid walls. USNM 172325, slide $7.2 . \times 136$.

7. Radial section through peripheral parenchyma zone (just outside secondary phloem region) showing clusters of sclerotic cells. USNM 172325, slide 7.8. $\times 136$.

PLATE XI (see p. 22)

Diichnia readii $\mathrm{sp}$. nov.

1. Transverse section showing a pair of leaf traces (arrows). The leading trace, on the right, is just distal to its level of divergence. The trace on the left is still attached to the axial bundle. USNM 172325, slide 2. $\times 15$.

2. Transverse section of cortex containing a petiolar vascular supply distal to level of production of first branches. Note that the traces branch laterally in contrast to the medial branching in $D$. kentuckiensis. Also note abundant sclerotic clusters. USNM 172325, slide $1055 . \times 15$.

3. Outer sparganum cortex in transverse view. Note also sclerotic clusters, one with thin-walled central cells, the other with thickwalled central cells. USNM 172325, slide $23 . \times 20$.

4. Transverse section of phloem region. The phloem conducting cells which apparently were located between the rays, just inside of the peripheral parenchyma zone are not preserved. Note the cavities in the peripheral parenchyma zone which contained cells like those shown in Plate X, 7. USNM 172325, slide 2. $\times 20$.

5. Transverse section showing radially aligned cells in outer part of peripheral parenchyma zone. Note that these cells are continuous with radiating cells of the sclerotic clusters. USNM 172325, slide $1055 . \times 24$.

PLATE XII (see p. 23)

Diichnia readii $\mathrm{sp}$. nov.

1, 2. Transverse sections showing association of peripheral radiating cells of sclerotic clusters with the radially aligned cells in the peripheral parenchyma zone. Note, in 2 . that outer cells in the peripheral parenchyma zone are radially aligned only opposite the adjacent sclerotic cluster and that some of the cells of the sclerotic cluster form continuous files with cells of the peripheral parenchyma zone. USNM 172325 , slide $1056 . \times 15$ and $\times 24$, respectively.

3. Transverse section showing protoxylem strands (arrows) in the axial bundle and leaf trace just above the level of trace divergence. USNM 172325, slide 3. $\times 44$.

4. Transverse section illustrating two sclerotic clusters with conspicuous files of cells radiating from groups of central thin-walled cells. USNM 172325. slide $19 . \times 15$. 
PLATE $\mathrm{X}$
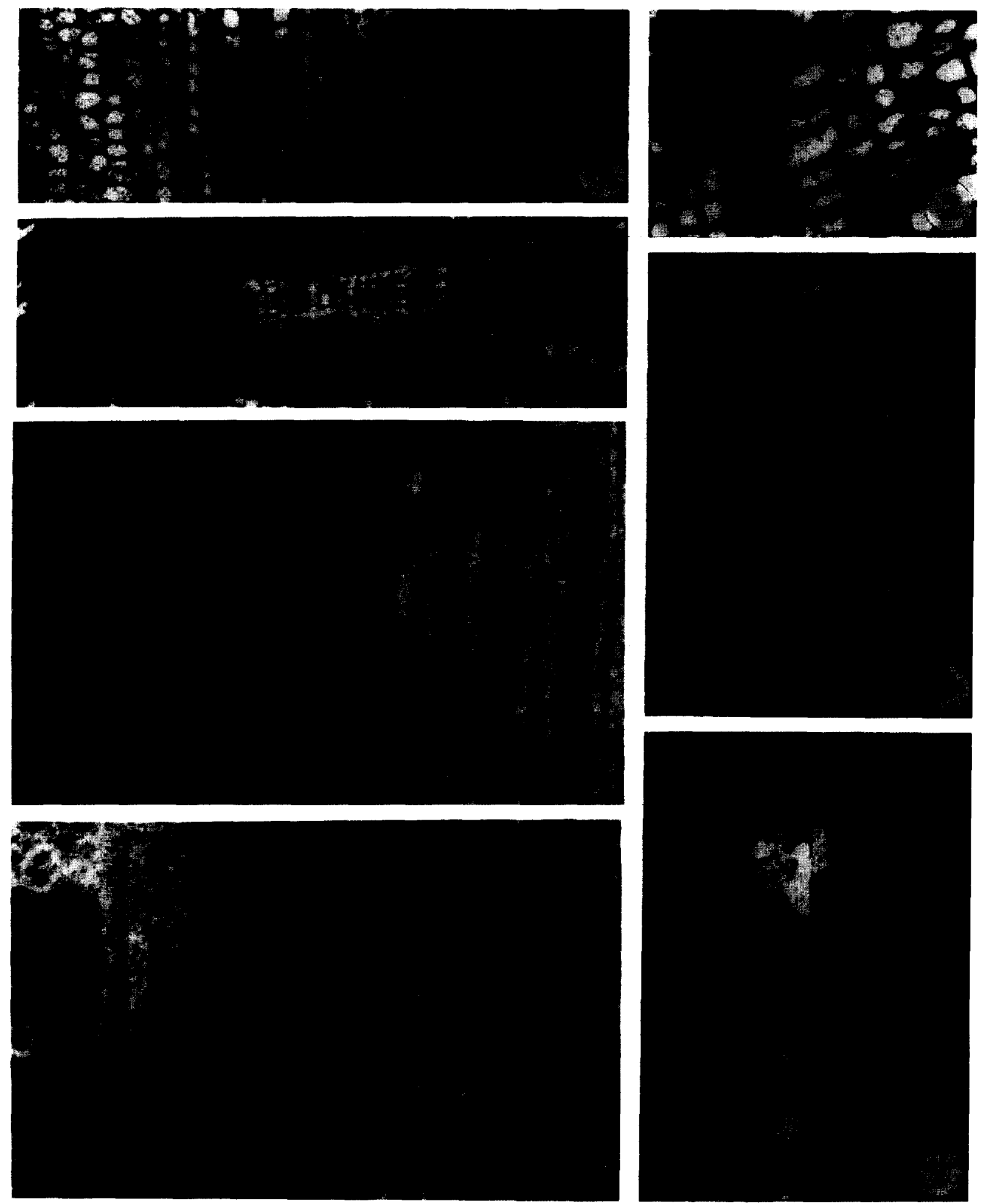


\section{PLATE XI}
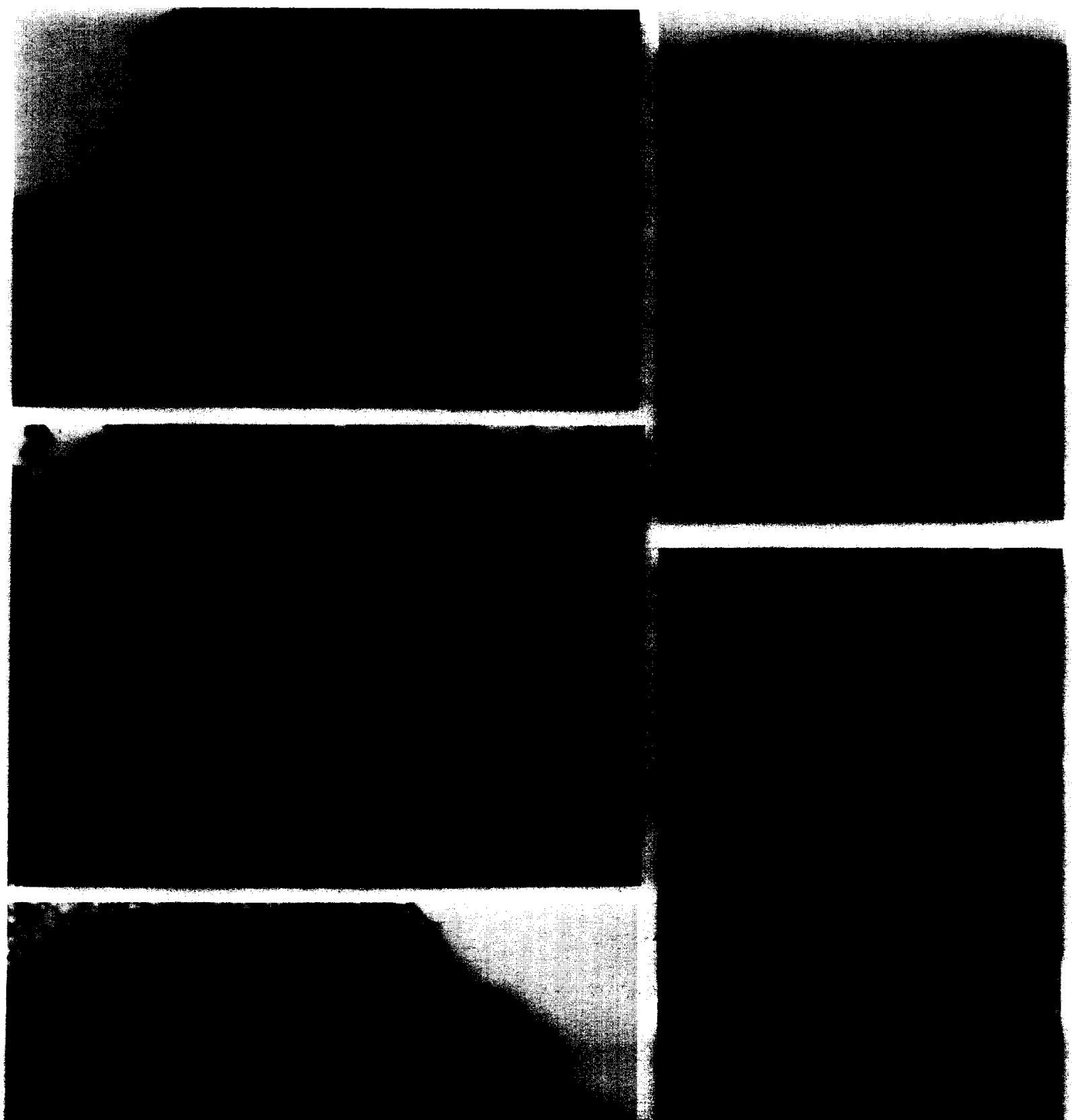

(for description see p. 20) 


\section{PLATE XII}
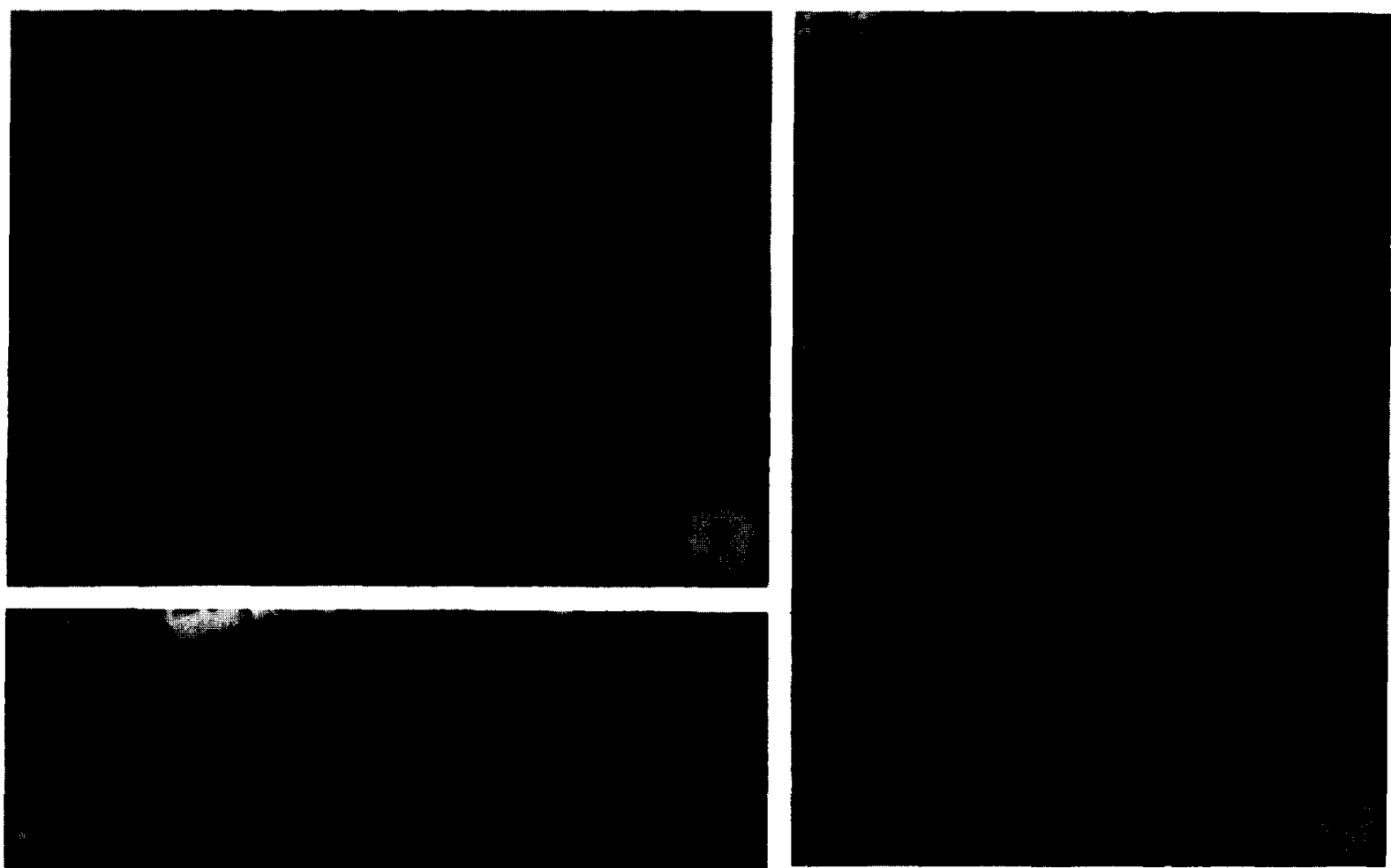

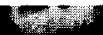

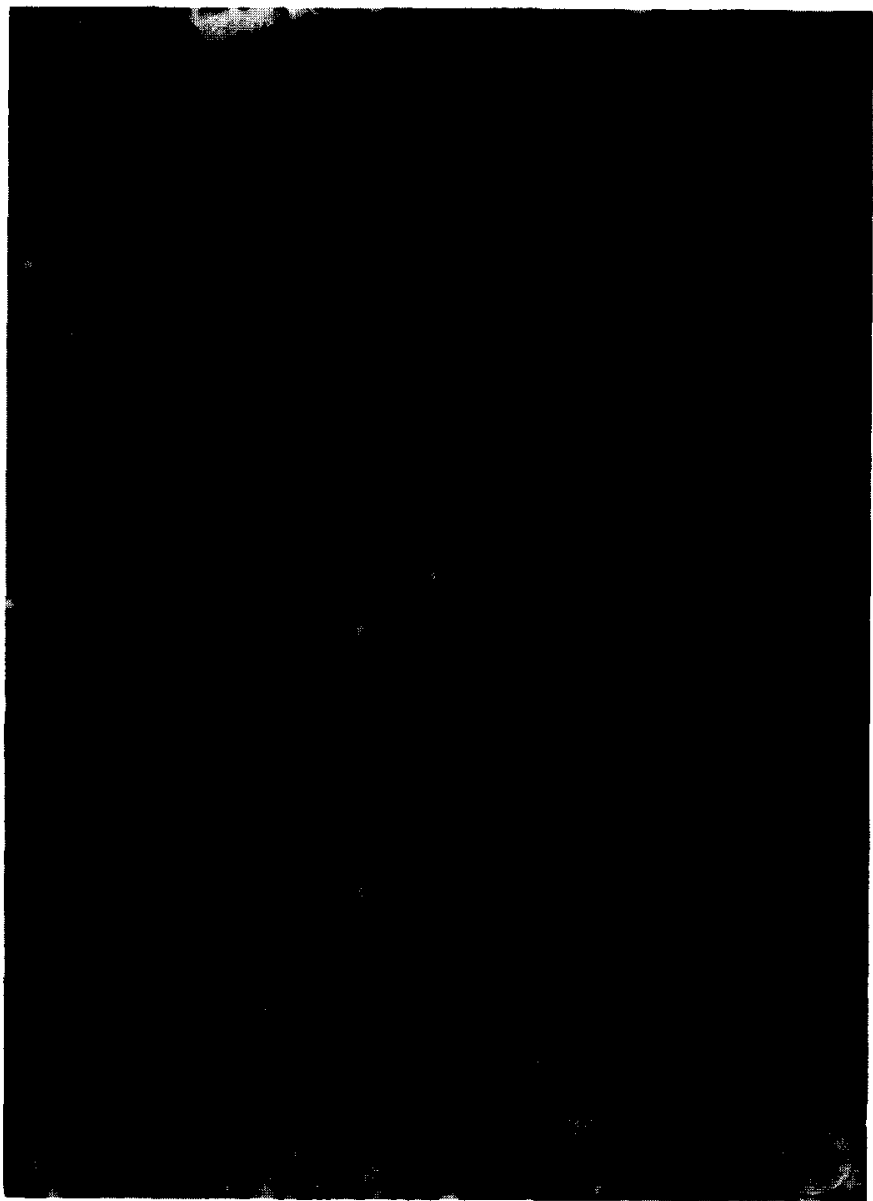

(for description see p. 20)

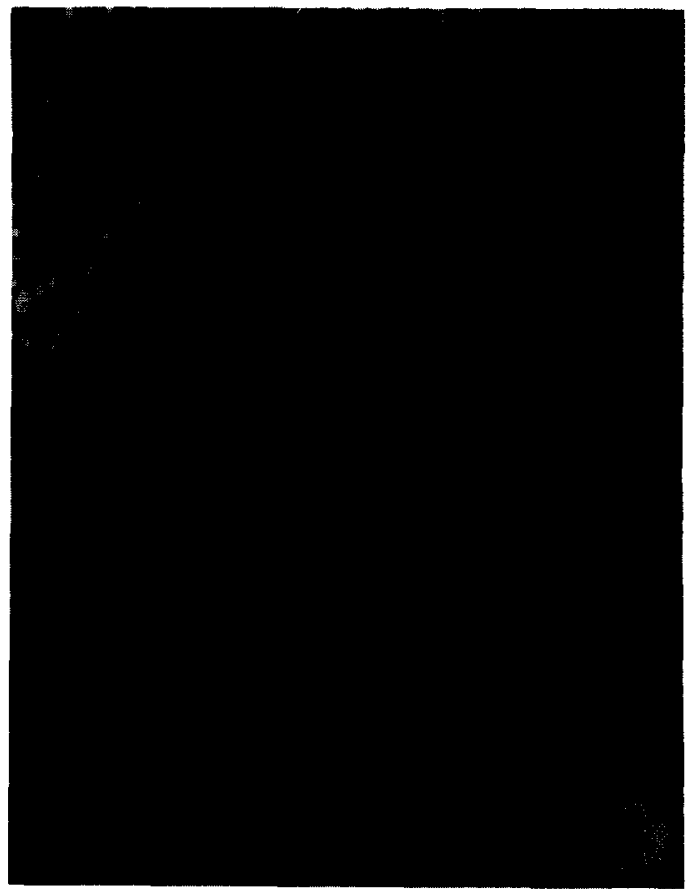


cells of these structures vary from $40-75$ (commonly 50) $\mu \mathrm{m}$ in diameter and 26-50 (commonly 30) $\mu \mathrm{m}$ in height. The cells that radiate from the central mass of cells are $150-480 \mu \mathrm{m}$ long by $50-123 \mu \mathrm{m}$ wide in transverse dimensions. The fibers in the outer sparganum cortex (Plate IX, 1; Plate XI, 3) are 30-68 (mean 48) $\mu \mathrm{m}$ in diameter and the parenchyma cells between plates of fibers vary from $40-80 \mu \mathrm{m}$ in radial, from $80-260 \mu \mathrm{m}$ in tangential dimension, and from $52-210 \mu \mathrm{m}$ in height.

\section{Discussion}

The analysis of stelar patterns is an activity that has engaged botanists since the latter part of the last century (see Beck et al., 1983). Whereas the utility of patterns of primary xylem bundles in phylogenetic analyses at the generic level is not well established, some characters are considered to be of importance at this level (Beck et al., 1983). We believe that patterns of leaf-trace divergence are important and that, when confronted with only permineralized vegetative axes, this and other features of the primary vascular system may provide useful taxonomic and phylogenetic evidence. In taxa in which discrete vascular bundles are not present, the patterns of protoxylem strands are commonly analyzed instead. The validity of this approach has been established by the work of Larson (1975), Benzing (1967a, b), Basinger et al., (1974) and others, and has been discussed at some length by Beck et al., (1983). Our analyses of the protoxylem patterns in the stele of Diichnia have shown a system consisting of five sympodia. The patterns show some variation, and in one axis a difference sufficient (with additional characters) to support the establishment of a new species.

\section{Stelar anatomy}

The specimens studied represent only about one internode (in one case slightly more than one internode). Thus, the stelar patterns proposed are based on a combination of evidence and extrapolation, and on the assumption that the pattern (or our interpretation of the pattern) observed in the available anatomically preserved segment is consis- tent throughout the system. That this may not be entirely true, however, is reflected in some variation in the stele of the specimen of D. kentuckiensis (41246) originally described by Read (1936b) and specimen 356463 (which we believe is part of the same specimen) on the one hand, and specimen 41247 a small axis that we interpret to represent the same species, on the other.

Of the specimens studied, USNM 172325, representing the new species $D$. readii (diagnosed below), provides the best and most easily interpretable evidence of it stelar architecture. Thus, we shall analyze it in detail and then compare the stele of other specimens with it. At levels just below trace divergence, adjacent axial bundles follow paths that bring them closer together (Fig. 7B). As the two traces to a leaf diverge, each from one of these axial bundles, one trace (always the one located opposite the direction of the ontogenetic spiral) diverges first, followed at a higher level by the second (Fig. 3A, 1-3, bundles $a, b$ ). We refer to the first of the two traces to diverge as the leading trace.

One may observe, proceeding distally (Fig. 3A, B; Plate IX, 4-6) that just proximal to the level at which the leading trace diverges radially from the axial bundle $(a)$, an accessory bundle diverges tangentially (or obliquely) in the direction of an adjacent axial bundle $(b)$ from which the second trace of the pair will diverge at a slightly higher level. Based upon available evidence, we hypothesize that this accessory strand runs longitudinally between these axial bundles for some distance before it fuses to the axial bundle from which it diverged (Plate IX, 3, 4; Fig. 3A, 1, 2, sympodium c) just below the level at which the next accessory bundle and, slightly more distally, the next leaf trace will diverge.

We can summarize this pattern as follows: prior to formation of a pair of traces, an accessory bundle fuses with the axial bundle from which the first trace of the pair will diverge. Distal to this level, but below the level of trace divergence, an accessory bundle separates from the axial bundle of the same sympodium. This sequence occurs repeatedly, with the axial bundle "receiving" and "producing" accessory bundles proximal to the level of trace divergence. The axial bundle along 
which these developmental "events" occur is always the one from which the first trace of the pair (i.e. the most proximal trace) diverges. The second trace of the pair departs from an adjacent axial bundle just distal to the level at which the leading trace diverges. This pattern is illustrated in a stelar diagram (Fig. 4B) depicted in one plane for specimen 172325. At certain levels three or
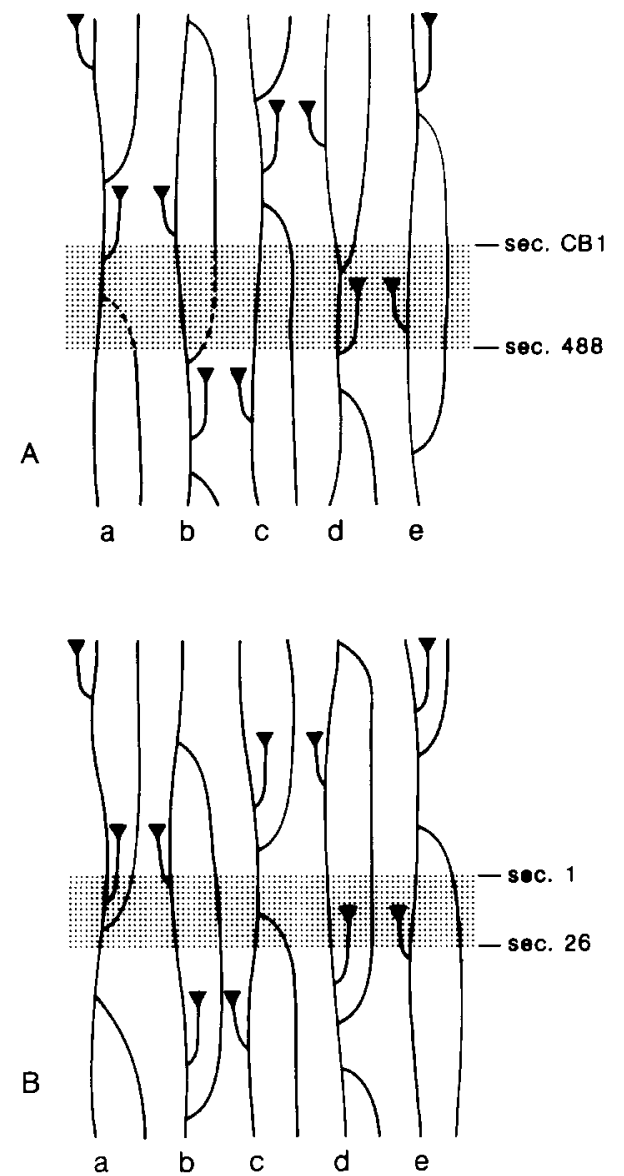

Fig. 4. A. Diagram of the primary vascular system of Diichnia kentuckiensis, specimen USNM 41247, shown in one plane and as viewed from the outside. Shaded region based on evidence from sections 488 , the most proximal section, through section CB1, the most distal (25 sections). Note that an accessory bundle fuses with the axial bundle below the level of leading trace divergence and branches from the axial bundle above the level of trace divergence. B. Diagram of the primary vascular system of $D$. readii specimen 172325 , shown in one plane and as viewed from the outside. Shaded region based on evidence from section 26 (proximal) through section 1. Axial bundles $a-e$ correspond to those in Fig. 3A. Note that an accessory bundle fuses to and branches from the axial bundle below the level of divergence of a leading trace. four free accessory bundles may be observed, with one or two others fused with the axial bundles (Plate IX, 2; Figs. 2C, 3A). At some levels five free accessory bundles may be observed alternating with the five axial bundles. However, if internodal length were increased and/or the distance over which accessory bundles remain fused with axial bundles were decreased, one would expect to see five accessory bundles at most levels. If we consider, in addition the variability (for which we have evidence) in the position of fusion and divergence of accessory bundles, we can account for the common appearance of only two or three accessory bundles in most sections in other specimens.

Details of the pattern of protoxylem strands in a sympodium at levels of fusion to and divergence from an axial bundle by an accessory bundle are illustrated in Fig. 3B. Note that the accessory bundle has lost its protoxylem strand at the initial level of fusion (Fig. 3B, 1, 2). The metaxylem of the accessory bundle seems to diminish over a distance of just under one internode and, we believe, ceases to exist (Fig. 3B, 1-3). At a lower level, the protoxylem of the axial bundle had divided (Fig. 3B, 1). The inner product of this division (the left protoxylem of the sympodium on the right) becomes with enclosing metaxylem the new accessory bundle. The other protoxylem strand divides into three (Fig. 3B, 3-5). The outermost of the three strands supplies the leaf trace (Fig. 3B, 5; see also Plate XII, 3), the central is the protoxylem of the continuing axial bundle, and the inner disappears distally (Fig. 3B, 6, 7). Note that in the adjacent axial bundle there is proximally only one protoxylem (Fig. 3B, 1, 2) which bifurcates to produce, with associated metaxylem, the leaf trace (Fig. 3B, 5, 6) followed by another bifurcation (Fig. 3B, 7, 8) prior to a predicted fusion with it of an accessory bundle.

\section{Variation in the stelar pattern}

\section{Specimen USNM 41247}

In this specimen (Plates VI-VIII; Fig. 1B), and others that we identify as $D$. kentuckiensis, we have good evidence for divergence of an accessory bun- 
dle above the level of divergence of the leading trace (Fig. 4A, sympodium $d$ ), and for continuity of accessory bundles through at least an internode (Fig. 4A, sympodia $c$ and $e$ ). There is no evidence of fusion of an accessory bundle with an axial bundle above the level of trace divergence. Consequently, we predict that fusion takes place below the level of divergence of the next leading trace to be produced in a sympodium. Thus, whereas in D. readii (specimen 172325; Plates IX-XII; Fig. 1C) accessory bundles fuse to and diverge from the axial bundles below the levels of divergence of leading traces, in specimen 41247 accessory bundles apparently fuse to the axial bundles below and diverge from axial bundles above levels of leading trace formation (Fig. 4A).

\section{Lectotype, USNM 4I246: specimen USNM 356463}

Specimen 356463 (Plates I-V; Fig. 1D), recently discovered in the Smithsonian collections, is identical in size and histological characteristics to the lectotype (USNM 41246; Fig. 1A), and is, we believe, a distal part of this same axis. When sequential sections of these specimens are arranged so that the divergence of traces follows the known phyllotactic pattern of Diichnia (Fig. 2A), the sizes and shapes of the stele and pith are comparable and conform to the pattern we would expect.

We do not, of course, know the length of the gap between these specimens. When the stelar pattern of these specimens is plotted in a combined diagram (Fig. 5), there is a general lack of continuity in the accessory bundles of the two specimens, although the accessory bundle that diverges from the axial bundle of sympodium $b$ is an exception. This fact, plus the divergence of two accessory bundles from the axial bundle of sympodium c between the production of successive traces suggests that the gap between these specimens is rather great, probably more than one internode. In both specimens, however, there are examples of accessory bundles diverging from, and a short distance beyond, fusing to, axial bundles (Fig. 5). This pattern may occur immediately proximal to the divergence of more persistent accessory bundles, as in sympodium e. Unlike the other specimens, accessory bundles may also diverge from both

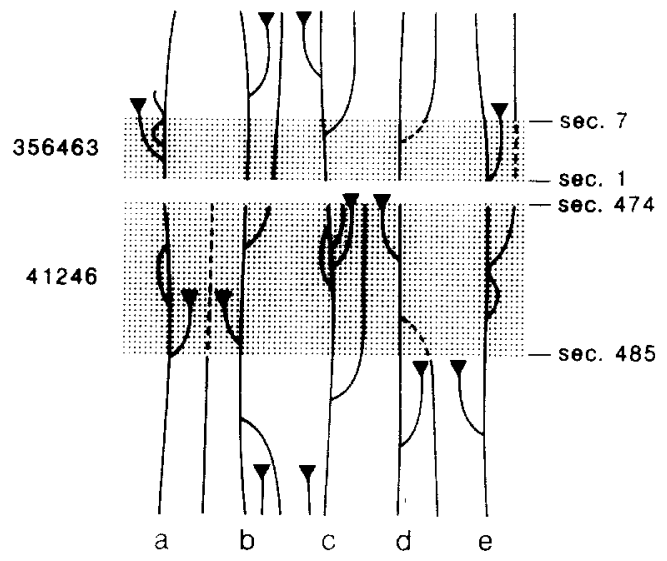

Fig. 5. Diichnia kentuckiensis. Composite diagram of the primary vascular system based on evidence (shaded areas) from two specimens (USNM catalog numbers at left) thought to represent the same stem. The vascular system is spread out in one plane and viewed from the outside. As in Fig. 4A (above) accessory bundles apparently fuse with axial bundles below and branch from them distal to levels of leading trace divergence.

sides of the axial bundles and in sympodium $c$ from both sides of the same bundle.

It is apparent that the stele of these specimens $(41246 ; 356463)$ is quite irregular in the pattern of accessory bundles, unlike the stele of specimens 41247 and 172325. As in specimen 41247, however, which we believe represents the same species (D. kentuckiensis), accessory bundles fuse to axial bundles below the levels of trace divergence, and apparently diverge above. The variation in the vascular pattern of $D$. kentuckiensis may reflect changes during ontogeny of the plant. Changes during ontogeny in sympodial number and vascular supply to leaves are well known in extant plants and have been documented in conifers by Camefort (1956) and in angiosperms by Jensen (1968), among others.

As in D. readii, specimens 41246 and 41247 are short segments of axes, the latter approximately one internode in length, the former about $11 / 3$ internodes. Thus, the evidence for our suggested patterns is not as strong as we would prefer.

\section{The petiolar vascular supply.}

In all specimens, the production of the pair of traces that provide the vascular supply to a leaf is 
asymmetrical (Fig. 1; Plate III, 1-3; Plate XI, 1). Consequently, the pattern of branching of these vascular bundles in the cortex is also asymmetrical (Figs. 3C, 6A, B). In the lectotype (41246), which is about twice the size of specimen 41247 , secondary xylem accompanies the traces for some distance (Fig. 6A). Note also that transverse elongation as well as division of the protoxylem strands of the leading trace precedes comparable changes in the other trace of the pair. Divisions of the protoxylem strands anticipate divisions of the petiolar bundles. New bundles are produced medially, resulting in a basal petiolar supply of six bundles (Fig. 6A). Exactly the same pattern characterizes specimen

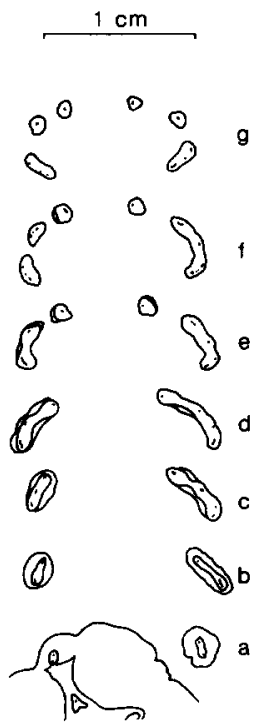

A

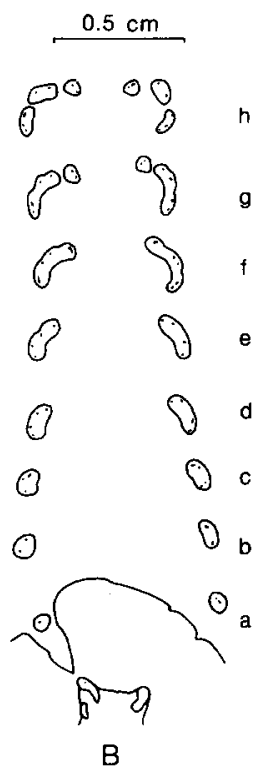

$B$
Fig. 6. Diichnia kentuckiensis. Series of diagrams representing, in each of two specimens, the branching of a pair of leaf traces that results in the petiolar vascular supply. Note that the specimen in $\mathrm{A}$ is more than twice the size of that in $\mathrm{B}$. In the larger specimen secondary xylem accompanies the traces for some distance through the cortex whereas in the smaller there is no secondary xylem associated with the traces. Note the assymmetry which results from the difference in level of divergence of each trace of the pair. Branching of traces in each specimen is medial. A. Specimen USNM 41246; A, $a=$ sec. 483, vascular supply to leaf 3 (compare with Fig. 1A); A, $b=$ sec. 478, leaf 3; A, $c=$ sec. 483, leaf $2 ; \mathrm{A}, d=\sec$. 480, leaf 2; A, $e=$ sec. 476 , leaf 2 ; A, $f=$ sec. 484 , leaf 2 ; A $g=$ sec. 478 , leaf 1. B. Specimen USNM 41247 ; B, $a=$ sec. CB23, vascular supply to leaf 3 (compare with Fig.1B); B, $b=$ sec. $\mathrm{CB} 10$, leaf 3; B, $c=$ sec. CB1, leaf $3 ; \mathrm{B} d=$ sec. CB23, leaf $2 ; \mathrm{B}, e=$ sec. CB10, leaf $2 ; \mathrm{B}, f=$ sec. $\mathrm{CB} 23$, leaf $1 ; \mathrm{B}, g=\sec$. CB7, leaf $1 ; \mathrm{B}, h=$ sec. CB2, leaf 1 .
41247 except that no secondary xylem accompanies the traces in the cortex (Fig. 6B). Specimen 172325 (D. readii) differs more significantly in that new bundles are produced from the outer (lateral) ends of the petiolar bundles (Fig. 3C). It is on this basis plus the difference in the stelar pattern noted above that have lead us to conclude that it represents a new species.

In this specimen (172325) the observed petiolar vascular supply consists of only four bundles, but the two larger medial bundles are in the process of further division which would, we believe, result in a basal petiolar supply of six bundles like that of the type species.

We agree with Read's (1937) suggestion that the specimen of Kalymma resinosa (illustrated in Read, 1937, fig. 23, 3) actually represents the detached petiole of Diichnia. Read considered the common occurrence of "lysigenous cavities" as proof of identity; however, we prefer to emphasize the similarity in both organization and size of the petiole vascular supply consisting of 5-6 tangentially oriented bundles. In the illustrated specimen of $K$. resinosa (Read, 1937, pl. 23, 3) the petiole vascular supply has a tangential width of $8 \mathrm{~mm}$ which fits with the variation observed above ( 5 to $12 \mathrm{~mm}$ ) in Diichnia petiole bases. However, we consider that other petioles assigned to $K$. resinosa by Read (1937, pl. 25, 3) or by Matten and Trimble (1978, textfig. 11A) actually represent a different taxon characterized by a broader vascular supply (15 $\mathrm{mm}$ in tangential width) consisting of more than 10 radially elongated bundles. Such petiole anatomy is consistent with that described in some specimens of Calamopitys.

\section{Origin of the peripheral parenchyma zone}

This conspicuous cylinder of tissue (Plate II, 1; Plate III, V), which Read described as pericycle, is apparently in contact with and peripheral to the secondary phloem, the outer limit of which we believe is indicated by the outer ends of the vascular rays (Plate $\mathrm{V}, 1,3$ ).

There are at least three possible interpretations for the origin of the tissue of the peripheral parenchyma zone. One is that it is a zone of secondary parenchyma produced by the vascular 
cambium prior to the development of the first secondary phloem. This seems the least likely of the three, although functionally tenable, since during the time this tissue was being produced, primary phloem could have provided the necessary means of transport of photosynthate. A second, more likely possibility is that this zone of parenchyma was derived through proliferation of ray and possibly also secondary phloem parenchyma. If so, this zone could be interpreted as a part of the secondary phloem. A third possibility, which we consider most likely, is that this tissue as well as the parenchyma separating the bundles of primary xylem from the secondary xylem reflects the presence of a meristematic zone in the shoot apices, perhaps comparable to what Esau (1977, pp. 288-289) called residual meristem in extant angiosperms. We envision a continuous cylinder of meristematic tissue in the shoot apex in which primary xylem and primary phloem differentiated as separate bundles. The vascular cambium apparently differentiated in this zone between these bundles. Upon becoming active, and with the production of secondary xylem, a zone of parenchyma representing the inner part of this meristematic zone separated the secondary xylem from the primary xylem. The outer part of this postulated zone would have been pushed outward by the production of secondary xylem and phloem. In order to maintain its continuity, it would have had to actively divide, thus resulting in its greater thickness and histological characteristics somewhat different from those of the tissue representing the inner part of the zone. Active cell division in this part of the zone may also have prevented its crushing during cambial activity. Tissue comparable in location and histology also characterized Triichnia (Galtier and Beck, 1992) and some species of Calamopitys.

\section{Origin of the sclerotic nests}

In a recent paper, Beck and Stein (1987) suggested that sclerotic clusters might not be normal histological features of calamopityacean plants but, rather, pathological responses to stimulation by insects or, possibly, viruses introduced into the tissue by insects. Although the three authors of the current paper disagree on the level of probability that this hypothesis will be proven correct. evidence from one of our specimens of Diichnia seems, at least indirectly, to support it. The conspicuous zone of parenchyma just peripheral to the phloem is characterized in specimen 172325 by regions in which the outer cells are arranged in radial files (Plate XI, 5; Plate XII, 1, 2). These regions are in contact and apparently continuous with the radiating cells of adjacent sclerotic clusters. Where there is no nearby sclerotic cluster, there is no radial alignment (i.e. evidence of cell divisional activity) (Plate XII, 2). This leads us to suggest that cell division, and the resulting radial alignment of cells in such regions of the parenchyma zone, are influenced, possibly caused, by the same factor(s) that cause(s) the development of the sclerotic clusters. This developmental activity is apparently local, occurs relatively late in the development of the stems, and is similar to that related to the formation of sclerotic clusters (see Beck and Stein, 1987. for a detailed rationale).

\section{Phylogeny}

Until recently, Diichnia was unique in being the only member of the Calamopityaceae characterized by a petiolar vascular supply derived from two sympodia, each contributing one of the pair of traces. We now know, however, that another genus, Triichnia gen. nov. (Galtier and Beck, 1992) shares the same feature, but differs in that three traces, two derived from one sympodium, and one from the other, provide the petiolar vascular supply. In Stenomyelon bifasciculare (MeyerBerthaud, 1984), Calamopitys americana (Scott and Jeffrey, 1914), Galtiera (Beck and Stein, 1987), and Bostonia (Stein and Beck, 1992) the petiolar vascular supply is also derived from a pair of traces, but these originate through bifurcation of the ends of ribs of apparent protosteles. Whether these traces are homologous with the pair of traces derived from separate sympodia in Diichnia is not clear at present.

The significance of the derivation of the leaf vascular supply from more than one sympodium 
in Diichnia and Triichnia is also unclear, but suggests the pattern of leaf trace divergence in the Medullosales. In this group multiple traces to individual leaves seem to be derived from several sympodia (Basinger et al. 1974; Stidd, 1981). The possible phylogenentic relationship of these taxa with the Medullosales is further discussed by Galtier and Beck (1992) and Stein and Beck (1992).

Diichnia, with its well defined eustele of five sympodia, also resembles Calamopitys, and among the species of Calamopitys, it resembles most closely C. foerstei (Read, 1937) in characteristics of the stele. Unfortunately, all known specimens of $C$. foerstei are decorticated and information on characteristics of the cortex and the proliferation of the petiolar vascular supply is currently unavailable. It is clear, however, that the vascular supply to a leaf originates from a single leaf trace as in other species of Calamopitys.

An ultimate goal of our long-range project is to understand the phylogenetic relationships of the calamopityacean taxa to each other and to ancestral as well as derived taxa. A first attempt at determining such relationships among taxa of the Calamopityaceae has been made by Stein and Beck (1992). A more comprehensive analysis awaits the completion of morphological and anatomical studies of all genera in the family.

\section{Systematics}

\section{Order LYGINOPTERIDALES}

Family CALAMOPITYACEAE

\section{Genus Diichnia}

Read, 1936a. J. Paleontol., 10: 219, pl. 27, fig. 2

Read, 1936b. USGS Prof. Pap., 185-H, pp. 149-161

Emended diagnosis: Stem with primary and secondary vascular tissues. Eustele consisting of five mesarch primary xylem bundles at the angles of a broad, five-angled, parenchymatous pith containing rare to centrally abundant medullary tracheids. Ratio of primary xylem (stelar) diameter to stem diameter small $(1 / 5$ to $1 / 6)$. Leaves helically arranged. Each leaf supplied by two traces originating separately from two adjacent axial bundles; one leaf trace (always the one opposite the direc- tion of the ontogenetic spiral) diverging more proximally. Axial bundles undulating, pairs coming closer together below levels of trace divergence. An accessory bundle diverging from and distally fusing to the axial bundle that produces the leading leaf trace (the more proximal of the pair to diverge). Leaf traces dividing systematically in the cortex supplying petiole bases with six circular to elongate and obliquely oriented vascular bundles. Primary xylem of axial bundles in contact with secondary xylem; accessory bundles slightly separated from secondary xylem. Secondary xylem tracheids with multiseriate pitting restricted to radial walls. Rays uniseriate to multiseriate and very high. Phloem zone containing secondary axial elements, and dilated rays which extend into a peripheral zone of parenchyma. Cortex consisting of an inner parenchymatous ground tissue containing sclerotic clusters and an outer sparganum zone.

\section{Type species: Diichnia kentuckiensis Read}

Emended diagnosis: Stem diameter 20-40 mm. Accessory strands fusing to axial bundles proximal to, and diverging from axial bundles distal to, levels of divergence of leading traces (the traces of the pairs that diverge more proximally). Number of accessory strands visible between axial bundles in transverse sections variable, commonly 2 or 3 . Leaf traces branching from their inner, medial ends to form petiolar vascular supply. Width (tangential) of vascular supply in petiole base 5 to $14 \mathrm{~mm}$. Pith (also stem primary xylem system) $2.6-9 \mathrm{~mm}$ in diameter. Pith parenchyma cells 26-180 (rarely to 420$) \mu \mathrm{m}$ in diameter, and 40-146 $\mu \mathrm{m}$ high (longitudinal dimension); pith tracheids $30-310$ (rarely to 526$) \mu \mathrm{m}$ in diameter. Metaxylem tracheids in axial bundles 26-200 $\mu \mathrm{m}$ in diameter. Secondary xylem $3.1-4.5 \mathrm{~mm}$ thick; tracheids $26-108 \mu \mathrm{m}$ in radial dimension and $26-88 \mu \mathrm{m}$ in tangential dimension; bordered pits to 8 -seriate, $12-16 \mu \mathrm{m}$ in diameter. Rays $1-12$ cell rows, $12-260 \mu \mathrm{m}$ wide, and greater than $3.15 \mu \mathrm{m}$ high. Ray cells $12-36 \mu \mathrm{m}$ in tangential and $104-160 \mu \mathrm{m}$ in radial dimensions, and $24-60 \mu \mathrm{m}$ high. Parenchyma cells in zone peripheral to region of conducting cells of the secondary phloem 
$40-110 \mu \mathrm{m}$ in diameter; sclerotic(?) cell clusters (often cavities) in parenchyma zone $40-200 \mu \mathrm{m}$ in diameter. Cells of inner cortex $52-104 \mu \mathrm{m}$ in radial dimension, 104-260 $\mu \mathrm{m}$ in tangential dimension, and $52-104 \mu \mathrm{m}$ high. Sclerotic nests $244-900 \mu \mathrm{m}$ in diameter and $150-530 \mu \mathrm{m}$ high (longitudinal dimension); central cells $51-108 \mu \mathrm{m}$ in diameter; peripheral radiating cells $37-95 \mu \mathrm{m}$ wide and $130-394 \mu \mathrm{m}$ long (transverse dimensions). Fibers of the outer cortex $50-112 \mu \mathrm{m}$ in diameter; intervening parenchyma cells $70-282 \mu \mathrm{m}$ in tangential dimension.

Lectotype: Specimen USNM 41246, Smithsonian Institution, US National Museum, Washington. DC, USA, 20560.

Lectoparatypes: Specimens USNM 41245, USNM 41247, and USNM 356463, Smithsonian Institution. US National Museum, Washington, DC, USA, 20560.

Illustrations: Lectotype - Figs. 1A, 2A, 6A; Read. 1936a, plate 27, fig. 2; Read, 1936b, plate 30. figs. 1 ; plate 31 , figs. $1-4$; plate 32 , figs. 3,4 . 7 . 8; plate 33, figs. 1-3, 5, 6. Lectoparatypes Specimen USNM 41245: Read, 1936b, plate 32. figs. 1, 2, 6. Specimen USNM 41247: Plates VI VIII; figs. 1B, fig. 2B, 6B, 7A, B; Read, 1936b. plate 32, fig. 5. Specimen USNM 356463: Plates I-V; fig. 1D.

Locality: Junction City, Kentucky, USA.

Horizon: Falling Run Member of the Sanderson Formation, New Albany Shale, of Tournaisian (probably $\mathrm{Tn} 1 \mathrm{~b}-2 \mathrm{c}$ ) age.

\section{Diichnia readii sp. nov.}

Diagnosis: Stem diameter to $20 \mathrm{~mm}$. Accessory strands fusing to, and diverging from, axial bundles proximal to divergence of leading traces (the more proximal leaf traces of the pairs). Four or five accessory strands visible between axial bundles. Leaf traces branching from outer, lateral ends to form petiolar vascular supply. Width (tangential) of vascular supply in petiole base $7 \mathrm{~mm}$. Pith (also primary xylem system) $3.6 \mathrm{~mm}$ in diameter. Pith parenchyma cells $42-125 \mu \mathrm{m}$ in diameter and $42-125 \mu \mathrm{m}$ high; pith tracheids $30-150 \mu \mathrm{m}$ in diameter. Metaxylem tracheids of axial bundles $20-112 \mu \mathrm{m}$ in diameter. Secondary xylem $2.2 \mathrm{~mm}$
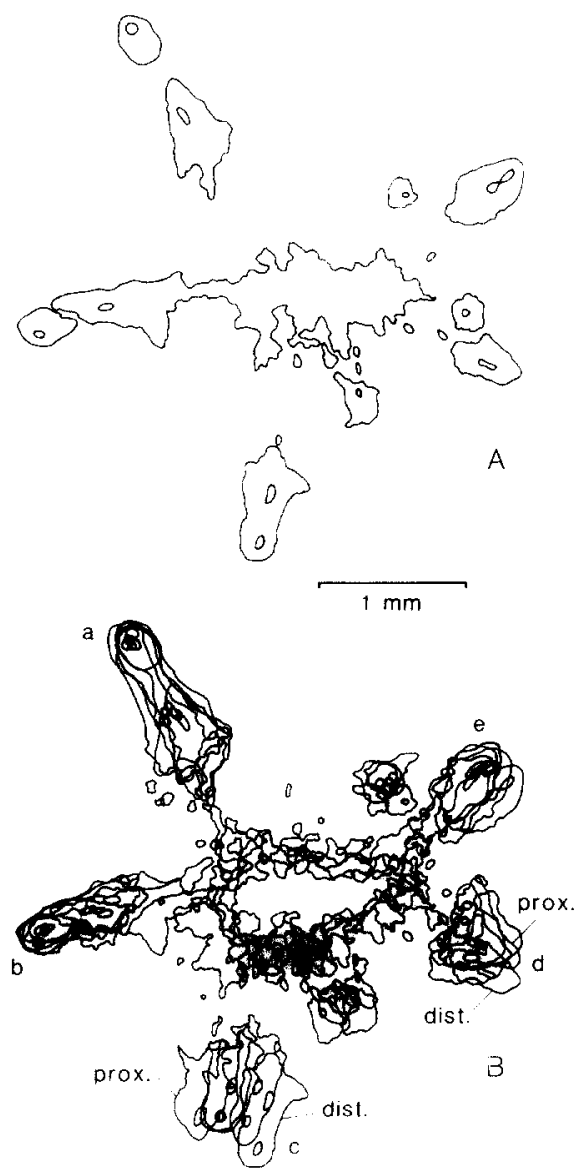

Fig. 7. Diichnia kentuckiensis. A. Camera lucida outline of primary vascular system plus associated tracheary tissue of the pith, in transverse view. USNM 41247, sec. CBI (the most distal section). B. Five sections stacked in ascending order. giving the appearance of an actinostele. Note that the axial bundles $(c, d)$ from which the next pair of traces will diverge become closer together as one proceeds distally through the stack of sections. USNM 41247, secs. CBI6, CB12, CBI0, CB5, CB1.

thick; tracheids $20-80 \mu \mathrm{m}$ in radial, and $20-72 \mu \mathrm{m}$ in tangential dimensions. Circular bordered pits to 6-seriate; approximately $10 \mu \mathrm{m}$ in diameter. Rays $1-8$ cells, and $18-160 \mu \mathrm{m}$ wide; greater than $1 \mathrm{~mm}$ high. Ray cells $14-30 \mu \mathrm{m}$ in tangential and $52-104 \mu \mathrm{m}$ in radial dimensions, and $10-40 \mu \mathrm{m}$ high. Parenchyma cells in zone peripheral to region of conducting cells of secondary phloem $40-104 \mu \mathrm{m}$ in diameter and $50-90 \mu \mathrm{m}$ high; sclerotic(?) cell clusters (often cavities) in parenchyma zone $65-205 \mu \mathrm{m}$ in diameter. Cells of inner cortex 
$80-260 \mu \mathrm{m}$ in diameter and $30-80 \mu \mathrm{m}$ high. Sclerotic nests $245-1034 \mu \mathrm{m}$ in diameter and $150-200 \mu \mathrm{m}$ in height (longitudinal dimension); central cells $40-75 \mu \mathrm{m}$ in diameter and $26-50 \mu \mathrm{m}$ high; peripheral radiating cells $50-123 \mu \mathrm{m}$ wide and $150-480 \mu \mathrm{m}$ long (transverse). Fibers of outer cortex $30-60 \mu \mathrm{m}$ in diameter; intervening parenchyma cells $40-80 \mu \mathrm{m}$ in radial and $80-260 \mu \mathrm{m}$ in tangential dimensions, and 52-210 $\mu \mathrm{m}$ high (longitudinal).

Holotype: USNM 172325, Smithsonian Institution, US National Museum Washington, DC, USA 20560.

Illustrations: Plates IX-XII; Figs. 1C, 2C, 3A, B, C.

Locality: Kentucky, USA. Precise locality unknown; probably Junction City, Boyle County. Horizon: Falling Run Member of the Sanderson Formation, New Albany Shale, of Tournaisian (probably $\mathrm{Tn} 1 \mathrm{~b}-2 \mathrm{c}$ ) age.

Derivation of name: The species is named for Charles B. Read in recognition of his significant contributions to our knowledge of the Calamopityaceae.

\section{Acknowledgements}

We express our gratitude to Dr. Francis Hueber for facilitating loans of material from the collections of the US National Museum, and granting permission to section previously unstudied specimens and uncut remainders of previously studied material. We are also indebted to J. Courbet, Institut des Sciences de l'Evolution, Université de Montpellier II, for drawing Fig. I, and to B. Miljour, Museum of Paleontology, University of Michigan, who rendered all other drawings. This study has been supported by a CNRS grant to Galtier and Meyer-Berthaud, NSF grant BSR 8113542 to Beck and Stein, NSF grant BSR 8306893 to Stein and Beck, and NSF grant INT8914710 to Beck and Stein.

\section{References}

Basinger, J.F., Rothwell, G.W. and Stewart, W.N., 1974. Cauline vasculature and leaf trace production in medullosan pteridosperms. Am. J. Bot., 61: 1002-1015.
Beck, C.B., 1970. The appearance of gymnospermous structure. Biol. Rev. Cambridge Philos. Soc., 45: 379-400.

Beck, C.B. and Stein, W.E., 1987. Galtiera bostonensis, gen. et sp. nov., a protostelic calamopityacean from the New Albany shale of Kentucky. Can. J. Bot., 65: 348-361.

Beck C.B., Schmid, R. and Rothwell, G.R., 1983. Stelar morphology and the primary vascular system of seed plants. Bot. Rev., 48: 691-815.

Benzing, D.H., 1967a. Developmental patterns in stem primary xylem of woody Ranales. I. Species with unilacunar nodes. Am. J. Bot., 54: 805-813.

Benzing, D.H., 1967b. Developmental patterns in stem primary xylem of woody Ranales. II. Species with trilacunar and multilacunar nodes. Am. J. Bot., 54: 813-820.

Camefort, H., 1956. Etude de la structure du point vegetatif et des variations phyllotaxiques chez quelques Gymnospermes. Ann. Sci. Nat. Bot. Ser. 11, 17: 1-185.

Campbell, G., 1946. New Albany shale. Bull. Geol. Soc. Am., 57: 828-908.

Esau, K., 1977. Anatomy of Seed Plants. Wiley, New York, NY, 2nd ed.

Ettensohn, F.R., Miller, M.L., Dillman, S.B., Elam, T.D., Geller, K.L., Swager, D.R., Markowitz, G., Woock, R.D. and Barron, L.S., 1988. Characterization and implications of the Devonian-Mississippian black shale sequence, eastern and central Kentucky, USA: Pycnoclines, transgression, regression, and tectonism. Devonian of the World, Proc. II Int. Symp. Devonian System, Calgary, Canada, (C.S.P.G. Mem. 14, II:) pp. 323-345.

Galtier, J. and Beck, C.B., 1992. Triichnia, a new eustelic calamopityacean from the Lower Carboniferous of France. Palaeontographica B, 224: 1-16.

Galtier, J. and Meyer-Berthaud, B., 1989. Studies of the early Carboniferous pteridosperm Calamopitys - a redescription of the type material from Saalfeld (GDR). Palaeontographica B, 213: 1-36.

Haas, W.H., 1956. Age and correlation of the Chattanooga shale and the Maury formation. US Geol. Surv. Prof. Pap., 286: $1-47$.

Jensen, L.C.W., 1968. Primary stem vascular patterns in three subfamilies of the Crassulaceae. Am. J. Bot., 55: 553-563.

Kidston, R. and Gwynne-Vaughan, D.T. 1912. On the Carboniferous flora of Berwickshire. I. Stenomyelon tuedianum. Trans. R. Soc. Edinburgh, 48: 263-271.

Larson, P.R., 1975. Development and organization of the primary vascular system in Populus deltoides according to phyllotaxy. Am. J. Bot., 62: 1084-1099.

Matten, L.C. and Trimble, L.J., 1978. Studies on Kalymma. Palaeontographica B, 167: 161-174.

Meyer-Berthaud, B., 1984. Stenomyelon from the Upper Tournaisian of the Montagne Noire (France). Can. J. Bot., 62: 2297-2307.

Read, C.B., 1936a. A Devonian flora from Kentucky. J. Paleontol., 10: 215-227.

Read, C.B., 1936b. The flora of the New Albany shale, 1. Diichnia kentuckiensis, a new representative of the Calamopityeae. US Geol. Surv. Prof. Pap. 185H: 149-161.

Read, C.B., 1937. The flora of the New Albany shale, 2. The Calamopityeae and their relationships. US Geol. Surv. Prof. Pap. 186E: 81-104. 
Sandberg, C.A., Ziegler, W., Leuterlitz, K. and Brill, S.M., 1978. Phylogeny, speciation and zonation of Siphonodella (Conodonta) Upper Devonian and Lower Carboniferous. Newslett. Stratigr., 7: 102-120.

Scott, D.H. and Jeffrey, E.C., 1914. On fossil plants, showing structure, from the base of the Waverley shale of Kentucky. Philos. Trans. R. Soc. London Ser. B, 205: 315-373.
Stein, W.E. and Beck, C.B., 1992. New information on Bostonia perplexa … an unusual member of the Calamopityaceae from North America. Rev. Palaeobot. Palynol., 72: 73-102. Stidd, B.M., 1981. The current status of medullosan seed ferns. Rev. Palaeobot. Palynol., 32: 63-101. 